TITLE:

COMMENTS ON SOME NEW AND ALREADY KNOWN CIRRIPEDS WITH EMENDED TAXA, WITH SPECIAL REFERENCE TO THE PARIETAL STRUCTURE

\author{
$\operatorname{AUTHOR}(S)$ :
}

Utinomi, Huzio

CITATION:

Utinomi, Huzio. COMMENTS ON SOME NEW AND ALREADY KNOWN CIRRIPEDS WITH EMENDED TAXA, WITH SPECIAL REFERENCE TO THE PARIETAL STRUCTURE.

PUBLICATIONS OF THE SETO MARINE BIOLOGICAL LABORATORY 1967, 15(3): 199-237

ISSUE DATE:

1967-10-30

URL:

http://hdl.handle.net/2433/175466

RIGHT: 


\title{
COMMENTS ON SOME NEW AND ALREADY KNOWN CIRRIPEDS WITH EMENDED TAXA, WITH SPECIAL REFERENCE TO THE PARIETAL STRUCTURE*
}

\author{
Huzio UTINOMI
}

Seto Marine Biological Laboratory, Sirahama

With Plate VI and 20 Text-figures

\section{Introduction}

The main aim of this paper is to describe a new species of the genus Acasta recently discovered and to revise some of the Balanus amphitrite complex hitherto known from Japan and the neighboring waters from modern taxonomical and anatomical aspects.

For these purposes, I have re-examined and dissected available materials of some important or problematic forms or subspecies of the "Balanus amphitrite" series contained in the extensive zoological collections of the Seto Marine Biological Laboratory and illustrated them in detail, when necessary, particularly in taking account of the parietal structure of the shell.

Our knowledge on the so-called "lame hypodermique" or "interlaminate figure" and "intralaminate figure" recently proposed to call for species identification of sessile Balanomorph barnacles has appreciably advanced by many contributions made particularly by some recent workers such as Davadie (1952, 1963), Cornwall (1956-1959), Harding (1962), Weisbord (1965), Newman, Zullo and Wainright (1967) and Ross and Newman (1967) since the time of Darwin's classics.

In early time of my cirripedological research I had already enumerated seven forms or subspecies of Balanus amphitrite DARWIN as occurring in the Japanese waters following the current manner of systematics adopted by earlier authors since DarwIN (cf. Hrro, 1938). Since I have published a short paper on the widespread B.a. hawaiiensis Broch (UTINom, 1960), this revisionary work, although not all I intend, has long been in mind, but its actual publication has been retarded till now, although further stimulated by Dr. HARDING's re-study of the DARwIN's types of varieties of $B$. amphitrite (1962) on the way of progress.

Now I am of opinion that Darwinian varieties are a conglomerate of several species and subspecies belonging to the subgenus Balanus s. str., some most closely

* Contributions from the Seto Marine Biological Laboratory, No. 471.

Publ. Seto Mar. Biol. Lab., XV (3), 199-237, 1967. (Article 12) 
related ones being to be recognized as subspecies, if considering the complicated structure of the compartments which involves the complex of the so-called "intraand interlaminate figures". However, the interlaminate figure, discussed by DAVADIE and CoRNWALL is practically less important and rather technically exacting to examine for the systematic purpose solely. Therefore, I treat here solely the basal edge of the compartments after the calcareous basis was carefully detached off, without sectioning the wall shell itself, in order to detect the relationship between the allied forms in the $B$. amphitrite complex and the other group concerned here.

This paper deals with the following ten species and subspecies of which the taxa are newly emended:

1. Balanus amphitrite amphitrite DARwIN sensu HARDING $(=B$. a. hawaiiensis Broch, 1922)

2. Balanus uliginosus, nom. nov. (=B. a. kruggeri Nilsson-Cantell, 1932)

3. Balanus pallidus Darwin (=B. a. pallidus and B. a. stutsburi Darwin, 1854)

4. Balanus albicostatus albicostatus Pilsbry ( $=B$. a. albicostatus Pilsbry, 1916)

5. Balanus albicostatus formosanus Hiro (=B. a. forma formosanus Hiro, 1938)

6. Balanus variegatus cirratus DARwin ( $=$ B. a. cirratus DARwin, 1854)

7. Balanus reticulatus nom. nov. $(=B$. a. communis DARwIN, partim; B. a. tesselatus UTinomi, 1964)

8. Acasta spinifera spec. nov.

9. Creusia indica (Annandale) (=C. spinulosa var. 11 Darwin, 1854; C.s. forma angustiradiata BRoch, 1931; Pyrgoma indicum ANNANDAle, 1924)

10. Megatrema oulastreae (UтіNomi) (=Pyrgoma oulastreae UTiNomi, 1962)

\section{Revised Descriptions and Discussions}

\section{Balanus amphitrite amphitrite DARWIN sensu HARDING}

\section{(Japanese name: Tatezima-huzitubo)}

(Plate VI, fig. 1)

B. a. var. (1) communis Darwin, 1854, p. 240 (partim).

B. amphitrite: Pilsbry, 1907, p. 190; Pilsbry, 1927, p. 312-Oahu, Hawaii.

B. a. communis: Nilsson-Cantell, 1921, p. 311, fig. 64-Messina, Mediterr. and Sunda Is.; Nilsson-Cantell, 1931, p. 122, fig. 3-many localities of Europe and Cape of Good Hope; Nilsson-CANtell, 1938b, p. 36, fig. 7-Madras and other localities along the Ind. Ocean.

B. a. forma hawaiiensis Broch, 1922, p. 314, fig. 56-Pearl Harbour, Honolulu and Kaladis Point, Mindanao.

B. a. var. denticulata BRoch, 1927, p. 133, fig. 14-Suez Canal; Stubings, 1961c, p. 23, fig. 4 from ship-hulls.

B. a. hawaiiensis: HIRo, 1937, p. 432, figs. 20-21-Seto; Hiro, 1938, p. 304, fig. 4-Misaki, Seto, Kure, Sasebo and Maizuru (all of Japan); Nilsson-Cantell, 1938b, p. 40, fig. 9-Persian Gulf; Hiro, 1939, p. 260-Taiwan; Utinomi, 1949, p. 22-Sasebo; Utinom, 1956, p. 52, pl. 26, fig. 8 (colored); Utinomi, 1960, p. 43 (synonymy); Stubbings, 1961a, p. 173-Persian Gulf; Ross, 1962, p. 12, figs. 1-5-western Mexico. 
B. amphitrite: Southward and Crisp, 1963, p. 27, fig. 11 (colored); Stubbings, 1963, p. 15Las Palmas, Gran Canaria.

B. a. amphitrite: HARding, 1962, p. 274, pls. 1-2 (revision); Stubbings, 1964b, p. 337-Angola; Stubbings, 1965, p. 886-Senegal; Newman et al., 1967, pp. 168, 170.

Description: For details see Hiro, (1937, p. 432 and 1938, p. 304) and Utinomi (1960, p. 43) for Balanus amphitrite hawaiiensis and HARDING (1962, p. 274) for Balanus amphitrite amphitrite, as cited above.

Remarks: As mentioned by Newman et al. (1967, p. 170, footnote) very recently, there has been considerable confusion upon this taxon. This is mainly due to DARwIN's inadequate description and inadvertent muddling up of separate varieties, samples and opercular valves (internal bodies too) from different sources. So presumably earlier authors including myself too might have been much perplexed in identification and nomenclature. Indeed, eminent cirripedologists Drs. BRoch and NiLsson-Cantell have often confused communis and hawaiiensis (or denticulata) and on other occasions treated as different subspecies or forms. These carlier procedure has misled most of later workers on the taxonomy of cirripeds. Dr. Harding of the British Museum (Nat. Hist.) has attempted to re-examine the original specimens of various varieties of Balanus amphitrite which DARwIN himself studied and dissected, and then he has designated lectotypes and proposed a revised nomenclature according to the modern usage of nomenclature.

He has designated a complete specimen chosen from about forty specimens on a piece of bamboo from Natal, South Africa on which the name Balanus amphitrite is clearly written by DARwIN's hand as referable to var. (1) communis of DARwIN. The photographs of B. a. amphitrite, thus renamed by him (HARDING, 1962, pl. 1-outer shells, opercular valves and cross section of a paries; pl. 2-mouthparts and cirri) clearly agree with $B$. a. hawaiiensis BROCH, the types of which I could re-examine through the courtesies of Dr. Torben WolfF of the Zoological Museum, Copenhagen, Denmark. Curiously enough, the tergum (Harding's pl. 1, figs. $e$ and $f$ ) does not correspond to Darwin's pl. 5, fig. $2 l$ for var. communis. HARDING, however, gave no mention on this point. The original diagnosis of var. communis given by DARwIN, i.e. "only one or two of them have a narrow spur" is too brief and vague diagnostically to understand.

On the other hand, the tergum of var. pallidus figured by DARWIN (1954, pl. 5, fig. $2 k$ ) seems to be similar to that of var. communis (i. e. B. amphitrite amphitrite now called) which HARDing photographed (his pl. 1, fig. f) ${ }^{1}$, as well as that of $B . a . h a-$ waiiensis BROCH.

Probably the materials on which DARwIN himself based to illustrate had been lost in the time of writing.

1) On this point, HARDing (1962, p. 280) only mentions as follows: "I do not believe the tergum figured by Darwin is of this species (i. e. B. pallidus pallidus DarwIN)." 
As mentioned above, the original diagnosis of var. (1) communis DARwIN does not exactly agree with HARDING's description and illustrations. However, to avoid further confusion in nomenclature I here follow the revised nomenclature proposed by Harding, as he is the first revisor of the Darwin's types. Further I will discuss on this problem in the section of Balanus reticulatus (nom. nov.).

\section{Balanus uliginosus Utrinomi, nom. nov. (Japanese name: Doro-huzitubo)}

(Text-figs. 1-2; Plate VI, figs. 4-6)

B. amphitrite var. niveus: KRÜGER, 1911, p. 51, pl. IV, fig. 35 (opercular valves only)-Making, Pescadores. (not DARwin)

B. a. krügeri Nilsson-CANTELL, 1932, p. 24, textfig. 10, pl. I,-Japan (exact locality not mentioned, but presumably Tokyo Bay).

B. a. krïgeri: HiRo, 1938, p. 305, fig. 5 (opercular valves only-Omori, Tokyo Bay; Iki Is.; southwest Korea; HIRo, 1939, p. 263-from ship-hulls in Takou, came from Kwanchow, South China; Utrnomr, 1949, p. 22 (listed only)-Ariake Sound oyster farms and Tomioka, Amakusa Is.; Utinomi, 1956, p. 52, pl. 26, fig. 9 (colored); Tarasov and Zevina, 1957, p. 190, fig. 75 (cited only); Utinomi, 1962, p. 216 (listed only)-Nomosaki; Zevina and Tarasov, 1963, p. 93, fig. 12 (opercular valves)-Tangku, Paiho River-estuary; Yantai, N. of Shantung Penin., North China.

Material Examined: (1) Omori laver-culture bed, Tokyo Bay. Coll. the late Dr. Kintaro Okamura. (2) Kunsan, Mokpo and Hanchon (all of the southwest coast of Korea). Coll. the late Dr. Shiro Okuda. (3) Hama oyster-culture farm, Ariake Sound. Coll. Mr. Saburo Inuo. (4) Kasaoka Bay, Seto Inland Sea. Coll. Dr. Shinichiro Fuse. (5) Tatigatani Inlet, Tanabe Bay. Coll. H. Utinomr, 1934.

Lectotype. One specimen selected from the material from Tatigatani Inlet, Tanabe Bay and deposited in the museum of the Seto Marine Biological Laboratory, registering as SMBL-Type 204, together with 2 paralectotypes.

Size of Types. Lectotype-Carino-rostral diameter $24.5 \mathrm{~mm}$, height $24 \mathrm{~mm}$, orificial diameter $17 \mathrm{~mm}$.

Paralectotypes - Carino-rostral diameter $26.5 \mathrm{~mm}$, height $25 \mathrm{~mm}$, orificial diameter $16 \mathrm{~mm}$; carino-rostral diameter $23 \mathrm{~mm}$, height $14.5 \mathrm{~mm}$, orificial diameter $15 \mathrm{~mm}$.

Supplementary Description: The shell is typically tubulo-conical, the rostral side being convex and the carinal side steep or slightly upturned. The orifice is large, rhombic to ovate and moderately toothed around the margin. The basis is flat or concave.

The compartments are externally smooth, polished. The parietes are fawn in ground color, becoming darker purplish upward, and marked with dark purple narrow longitudinal stripes closely set, never crossed by any horizontal bands.

The radii are broad, quite white and with oblique summits. The alae are 
also with oblique summits and tinged with dark purple. The sutural edges of the compartments on both sides are transversely septate.

Internally, the sheath is one-half of the height, transversely striated on its upper two-thirds and dark purple colored except along the lateral margins and along the lower non-striated margin which is free from the inner lamina. The face of the inner lamina below the sheath is strongly ribbed equidistantly all throughout. These

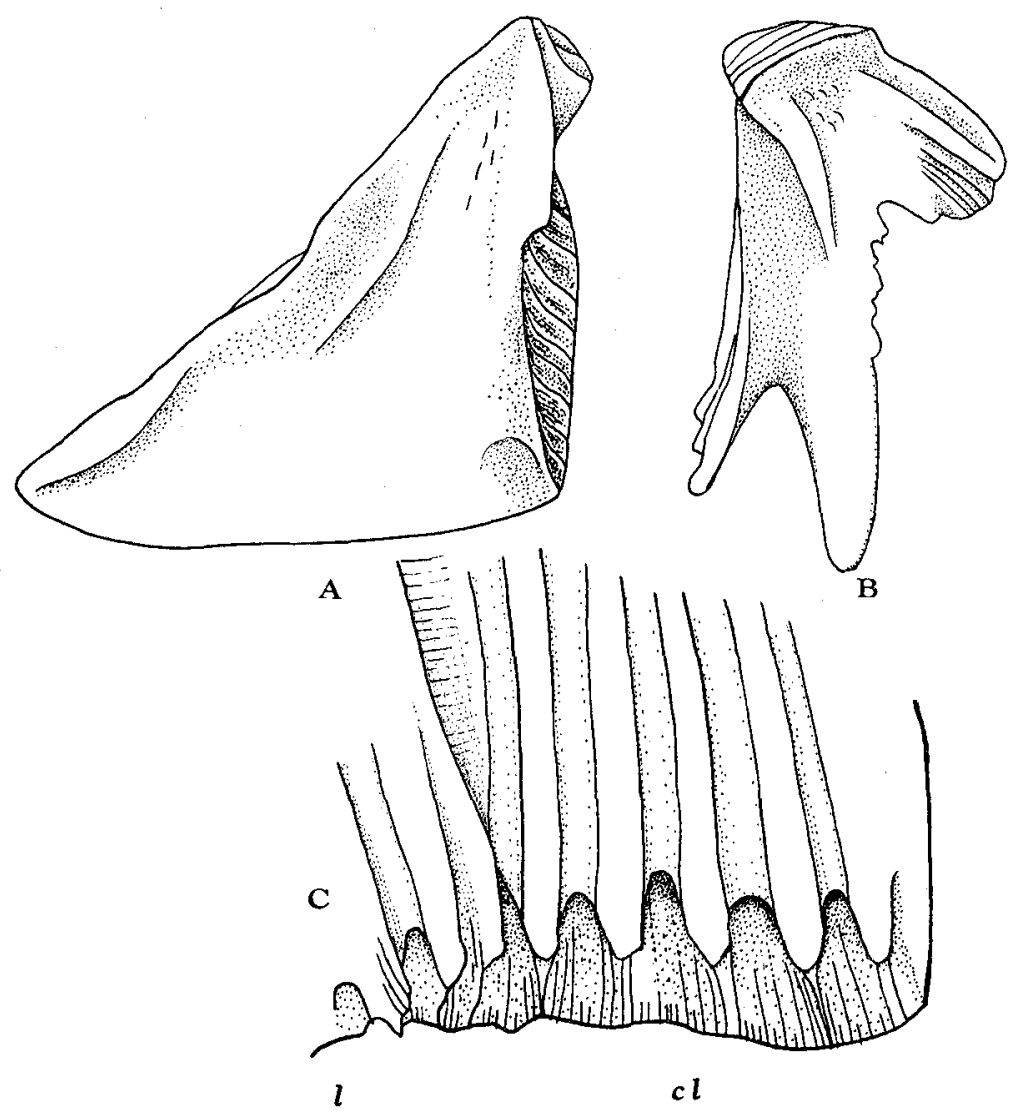

Text-fig. 1. Balanus uliginosus Utínomi, nom. nov, from Kasaoka Bay.

A, scutum, inner view. B, tergum, inner view. C, basal part of compartments, inner view. $c l$-carino-lateral compartment; $l$-lateral compartment. All $\times 12$

inner ribs (costae) are, as usual, flat or grooved up and 4-fluted on both sides, and their lower ends strongly project overhanging the thin primary septa which connect the inner and outer laminae of the wall. When well developed, there are numerous riblets or teeth in 2 orders inside the base of the outer lamina; the larger riblets lying within the parietal tubes may be said the incomplete secondary septa and the smaller denticles the tertiary teeth. The former (usually 1-3 per parietal tube) nearly reach 
the the crenated basal margin of the inner lamina, while the latter are only restricted to the basal margin of the outer lamina, interlocking the calcareous basis.

The parietal tubes are arranged only in one row between the inner and outer laminae and rectangular in section at base, and horizontally septate in the upper part of the wall.

The scutum is concave externally, either longer than wide or wider than long, dark purple in the middle broad depression, bounded by white elevations on both sides; the growth-lines are widely spaced, not rasied, but between them finely striated transversely. Internally, the upper part is smooth or slightly rugged and the adductor ridge is strong but short and the adductor depression is shallow; the pit for the lateral depressor muscles is obscurely indicated. The articular ridge is strong, about onehalf as long as the tergal margin, forming an articular lobe at apex.

The tergum is 3-prolonged in outline and quite flat externally, but with a shallow furrow where is white as in the carinal side; the scutal side is dark purple colored; the growth-lines are moderately developed. Of the three prolongations the spur is the longest, roundly pointed and the basal margin of the valve is deeply notched on both sides of the spur; the basal margin on its carinal side is usually strongly dentate, with 2-5 teeth. The basi-scutal angle is sharply pointed. The carino-basal prolongation is roundly truncated at end and bears about 5 long crests for the depressor muscles.

The mothparts are also characteristic as follows: The palp is distinctly clavate and bears a distal series of long setae. The labrum has invariably 4 teeth on each side of the deep median notch. The mandible has 5 teeth of which the second and third are bifid and the fifth one is shortly pointed and united with the pectinated inferior angle. The first maxilla has 12 spines of different size along the nearly straight frontal margin below the upper pair of large spines, and the lower part where is prominently protuberant than the upper two-thirds and bears 2 largest spines. The second maxilla is bilobed, rather small, the distal lobe being oval in outline and larger while the lower spherical and strongly setose.

The cirri in a specimen ( $14 \mathrm{~mm}$ in carino-rostral diameter) show the following number of segments :

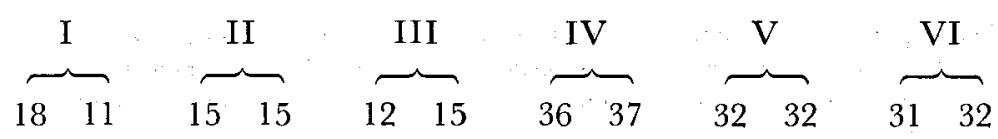

In cirrus I, the posterior ramus is about two-thirds as long as the anterior one. Cirrus II has subequal rami, formed of plump, protuberant segments. Cirrus III has also subequal rami and each segment is short, broad and bears 4-5 pairs of long setae on its protuberant frontal border and many spinules in distal series on both sides. In the posterior longer cirri IV-VI, both rami are subequal and each intermediate segment is quadrangular and armed with 3-4 pairs of long stout setae, 

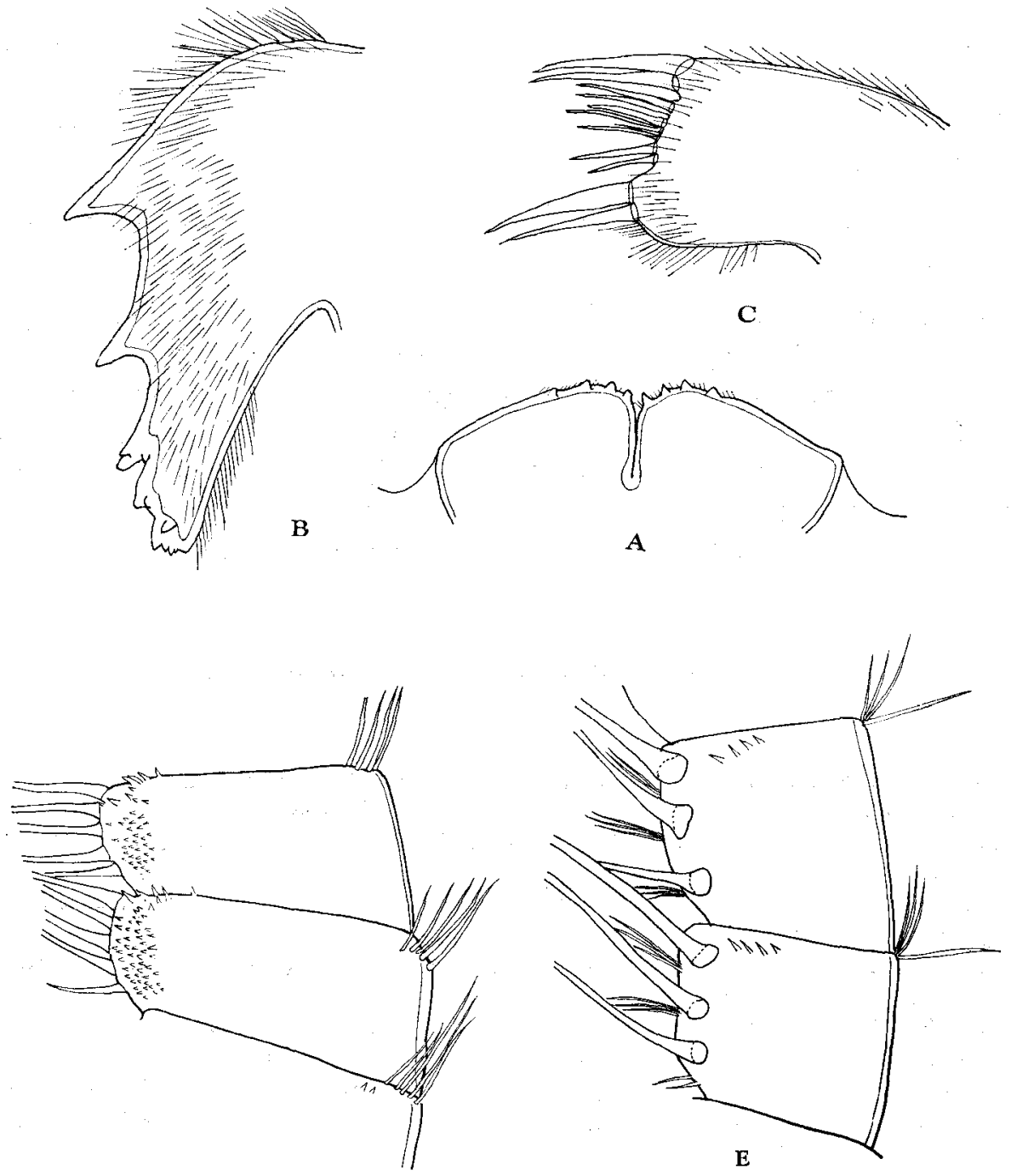

$\mathrm{D}$

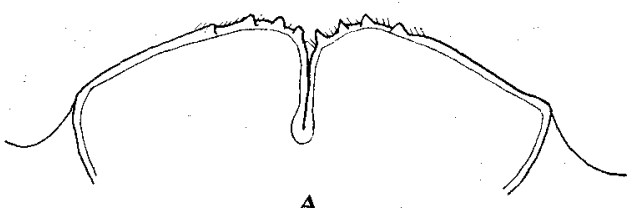

A

Text-fig. 2. Balanus uliginosus UтпNom, nom. nov. from Omori, Tokyo Bay (A-G) and Kasaoka Bay, Seto Inland Sea (D-E).

A, labrum. B, mandible. C, first maxilla. D, intermediate segments of posterior ramus of cirrus III. E, intermediate segments of cirrus VI. D-E, $\times 70$ 
accompanying a tuft of much smaller setae between each pair on the moderately curved anterior border and a tuft of smaller setae at the posterodistal angle; in addition a transverse row of spinules occurs near the anterodistal corner on both sides.

Habitat: This barnacle usually occurs in groups on bamboo or tree branches artificially set on muddy beds for oyster culture in less-saline quiet bays or estuaries. So it is essentially intertidal in habitat but rare on intertidal rocks or stones where Balanus albicostatus is abundant.

Distribution: Hitherto known only from southern Japan, southern Korea, China and Taiwan.

Remarks: This barnacle was first described by Nilsson-Cantell (1932) under the name of $B$. amphitrite krïgeri (n. ssp.) based on the material collected by Hilgendorf from Japan (possibly Tokyo Bay). According to the international code of nomenclature presently adopted, the name krüger is unfortunately inadmissible as it is preoccupied by Balanus krïgeri PILSBRY (1916) which is a valid species belonging to the other subgenus Chirona. Therefore, I propose here to raise it to the specific rank and to give a substitute name Balanus uliginosus as referring to its mud-dwelling habitat.

\section{Balanus pallidus DARWIN}

(Text-fig. 3)

Balanus amphitrite var. (3) pallidus Darwin, 1854, p. 240, pl. V, fig. $2 c$ (not fig. $2 k$ ).

B. a. var. (6) stutsburi DARwIN, 1854, p. 240 , pl. V, figs. $2 d, 2 i, 2 m-o$.

B. dybowskii Gruvel, 1903, p. 143, pl. I, figs. 1-9; pl. 4, fig. 14; Gruver, 1905, p. 257, figs. $270 \mathrm{E}$ et 286-Congo.

B. a. venustus: Nilsson-Gantell, 1925, p. 28, fig. 11 (not Darwin)-Kamerun (Cameroon), on mangrove roots.

B. a. stutsburi: Nilsson-Cantell, 1931a, p. 125, fig. 5-Kamerun (Cameroon); Nilsson-Canteld, 1938a, p. 179-Belgian Congo.

? B. a. insignis Nilsson-Cantell, 1938b, p. 41, fig. 11; pl. I, fig. 1-Sumatra, on wood.

? B. a. var. pallidus: Stubbings, $1961 \mathrm{c}$, p. 27, fig. 6 -tropical West Africa.

B. a. var. stutsburi: Stubbings, 1961c, p. 24, text-fig. 5-Trop. West Africa; Stubings, 1963b, p. 19, fig. 6-Banana Creek, Congo; SAndison, 1962, p. 517, figs. 3-12-Guinea Coast.

B. pallidus pallidus: Harding, 1962, p. 278, p1. 3, figs. a-r.

B. pallidus siutsburi: Harding, 1962, p. 281, pls. 4-5.

B. pallidus: StubBings, 1964b, p. 338, fig. 4-Congo Estuary; Stubbings, 1965, p. 887-Portuguese Guinea.

Material Examined: (1) Ikorudu, Lagos, Nigeria. Coll. Miss Eyvor E. Sandison. 1959. (2) Tromtway, Bombay, on submerged timber. Coll. Mr. A. B. WAGH. 1964.

Supplementary Description: The majority of West African specimens I have examined are, as repeatedly reported, wholly white, and the shell, when ag- 
gregated, tubulo-conical and nearly smooth externally, while a simple intact specimen collected at Bombay Coast is conical and dark purple-striped.

The scutum in a dissected specimen from Nigeria is wider than long, and has a short adductor ridge in the middle of the interior and a slight depression for the lateral depressor muscles; the rest is nearly smooth and the articular ridge is well developed, about one-half of the height and rectangularly angled at the lowest end, the articular lobe at the apex does not project so strongly. A broad triangular dark purple patch outside of the scutum is distinct in colored variant from Bombay.

The tergum is 3-prolonged as in the preceding B. uliginosus. The longest spur of three prolongations is gradually tapering and lies at about its own width distant
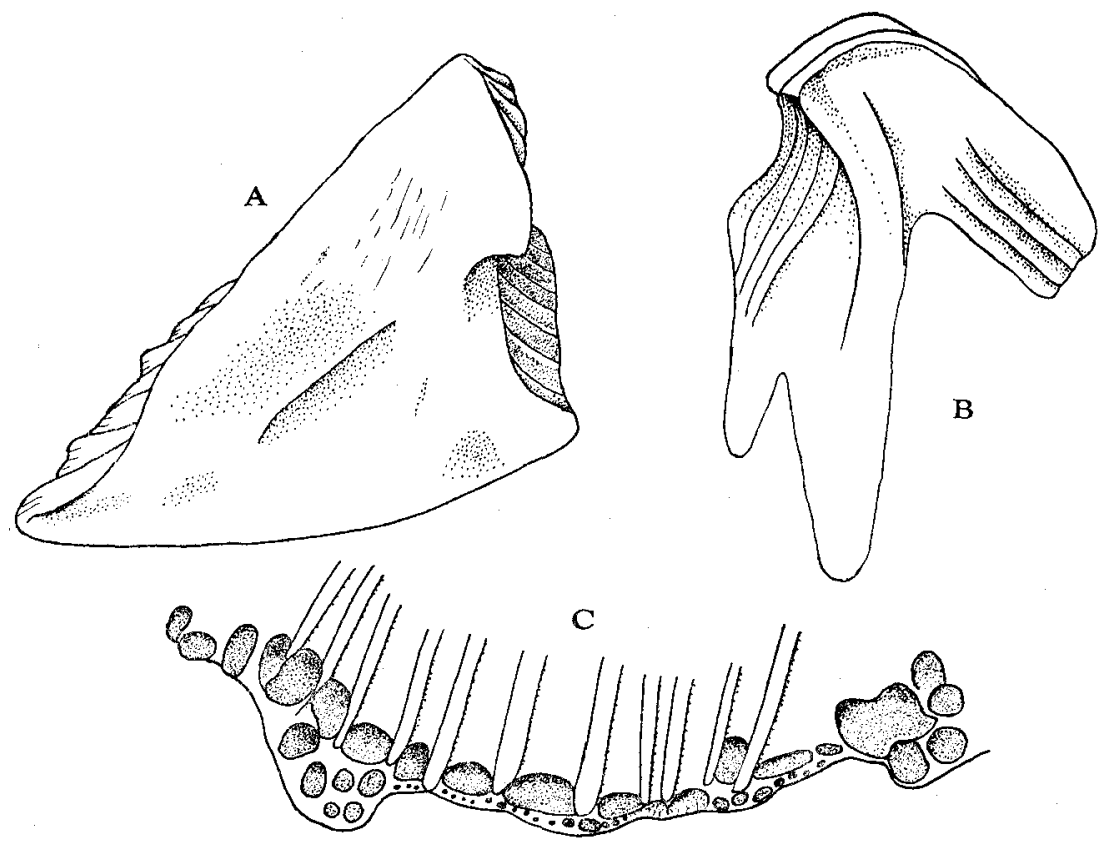

Text-fig. 3. Balanus pallidus DARwIN from Lagos, Nigeria.

A, scutum, inner view. B, tergum, inner view. $\mathrm{C}$, basal part of lateral compartment, inner view. All $\times 12$

from the sharply pointed basiscutal angle; its carinal side sloping to the wide notch of the basal margin is straight, lacking any teeth as seen in B. uliginosus. The basicarinal prolongation is truncated at end, about twice as long as wide and bears 2-3 long crests; the number of crests may be apt to vary considerably according to the degree of excavation of the basal margin. In any way, this prolongation is much more than the basi-scutal angle but lesser than the spur. The articular furrow is very broad. The exterior of both valves is quite flat, excepting a distinct spur fasciole. 
The parietes are predominantly white, although occasionally colored, as often pointed out by European authors. The nature of epidermis whether persistent or not that was emphasized by DARwIN for all varieties of $B$. amphitrite is of no systematic importance, because this depends largely upon the condition of preservation or the duration of time after collecting.

The face of the inner lamina below the sheath is ribbed. These ribs are relatively low, only developed in the lower half, slightly fluted on both sides, and terminate to rounded projections just above the marginal base of the outer lamina.

The parietal tubes are arranged in two layers, as clearly shown by the photographs of section of the parietal wall (cf. Harding, 1962, pl. 3, fig. $m$ and pl. 4, figs. $g-h)$. These parietal tubes are one-layered in the upper part and transversely septate as can be seen from the outside in much eroded material, while at the base the pores are relatively smaller than those of the one-layered porous forms or species of Balanus, round to oval in outline and in the thick-walled part of the basal margin they are apt to arrange more irregularly, probably by adding with marginal growth increments. This is also the case with other multiporous species of Balanus (e. g. B. gregarius, $B$. nubilus and $B$. cariosus) and Tetraclita. Furthermore, the outer lamina is slightly thicker than the inner lamina and normally smaller subsidiary pores are arranged in one row irrespective of occurrence of primary parietal pores stated above. It should also be noted that the basal edge of these primary and subsidiary pores is quite entire, without any teeth.

Concerning the internal animal body, further descriptions or comments would be superfluous, as they have been fully described by SAndison, StubBings and HARDING in particular.

Habitat: Strictly intertidal, on moles, shells or mangrove roots in less-saline lagoons, estuaries or protected harbors.

Distribution: Hitherto known with certainty from West Africa and west coast of India.

Remarks: Although we recognize Darwin's inadmissible mistake shown in the disagreement between his diagnosis and illustrations for var. pallidus, as very lately noticed by HARding (1962), the procedure of uniting together Darwin's two varieties pallidus and stutsburi under one name, as done by Stubbings (1965) for the first time, seems to be systematically reasonable. He (1963b) also regarded Gruvel's Balanus dybowskii as a heavily eroded form of $B$. pallidus. I support both of his disposal. But, I am not in agreement with HeNRY (1959), regarding a barnacle intruded into Potomac River on the Atlantic coast of North America as B. a. pallidus Darwin. In fact, brief photographs given by her (pl. I, fig. 4; pl. 3, fig. 7, middle in the lower row and fig. 8) may suggest to be referable to either B. improvisus or B. eburneus, common there.

The unusual multiporous structure of the wall in this species represents its unique 
status within the $B$. amphitrite complex currently treated, apart from the apparent similarity of the opercular valves to those of the preceding $B$. uliginosus known only from the East Asiatic coasts. Although this species may plainly be accepted as belonging to the series of $B$. amphitrite, one of the eight series that PiLsbry (1916) grouped non-critically, such peculiarly perforated wall may suggest a near affinity to the series of $B$. perforatus, especially fossilized $B$. laevis on the other hand (cf. Pilsbry, 1916, pls. 27-28; Davadie, 1963, pls. XI-XII).

\title{
4. Balanus albicostatus albicostatus PILSBRY (emend.) (Japanese name: Sirosuzi-huzitubo)
}

\author{
(Text-figs. 4-5 and Plate VI, fig. 2)
}

? Balanus violaceus GruVEL, 1903, p. 133, pl. 1, figs. 11-14; pl. 4, fig. 12; GRUVEL, 1905, p. 227, figs. $254 \mathrm{~A}$ et 255-unknown locality. (The name violaceus is preoccupied by Lepas violacea Gmelin, being a Balanus, after Pilsbry.)

B. amphitrite communis: $\mathrm{K}_{\mathrm{R} U \mathrm{UGER}}, 1911$, p. 51, pl. I, fig. 7; pl. IV, fig. 34 (40 is typographical error)Hongkong; Yokohama.

B. a. albicostatus PILSBry, 1916, p. 90, text-fig. 18; pl. 20, figs. 1-4-Yedo Bay, Shinagawa (both in Tokyo Bay) and Hirado, Kyusyu.

B. a. albicostatus: Nilsson-Cantell, 1921, p. 314-Hongkong, Kobe and Yokohama; Hiro, 1938, p. 303, fig. 3 (opercular valves-various localities of Japan, from Asamusi to Isigaki-zima and Korea; Utinomi, 1949, p. 22 (listed only); Tarasov and Zevina, 1957, p. 183, fig. 65 (cited only); Utinomi, 1956, p. 52, pl. 26, fig. 10 (colored); Zevina and Tarasov, 1963, p. 91, fig. 11 (opercular valves and mouthparts)-Lüta, Yantai, Tsingtao, Chusan Is. and Hainan Is. (all of Chinese coasts).

B. albicostatus albicostatus: UтіNomı, 1966, p. 5 (listed only)-Tomioka and Nomosaki.

Types: USNM no. 32950 from Japan, deposited in the U.S. National Museum, Washington, D. C.

Material Examined: Hatakezima Islet in Tanabe Bay. H. Utinomi Coll. 1942.

Supplementary Description: The shell is usually tubulo-conical, with a broad rhombic orifice hardly toothed. The exterior of the parietes is prominently ribbed; the interspace between these white ribs is colored dark Indian red to dark purple, but often some of these ribs are barely raised; if so, the parietes are partly smooth and simply longitudinally striped.

The radii are very broad, purplish or pink tinted and their summits are moderately oblique. Sutural edges of the radii are strongly septate transversely, each septum being denticulate downwards.

Internally, the sheath is rather short and the face of the inner lamina is strongly ribbed all throughout. These inner ribs are slightly fluted on both sides and bluntly terminate at the basal margin and then continue to the longitudinal septa separating the parietal tubes. These parietal tubes have numerous transverse septa in the 
upper part, but in the lower half they are rather large and open. The longitudinal septa between the tubes bifurcate at their bases close to the outer lamina, forming one or two subsidiary pores between the larger primary pores; both pores are relatively large and squarish to triangular at base. These primary and secondary parietal tubes correspond to the purple stripes or furrows between the ribs on the outside.

The scutum is wider than long, with a broad dark purplish triangular pattern on the outside. The interior is usually roughened with tubercles in the upper part. The pit for the adductor muscle is distinctly doubled and the pit for the lateral depressor muscles is also distinct. The articular ridge strongly projects beyond the

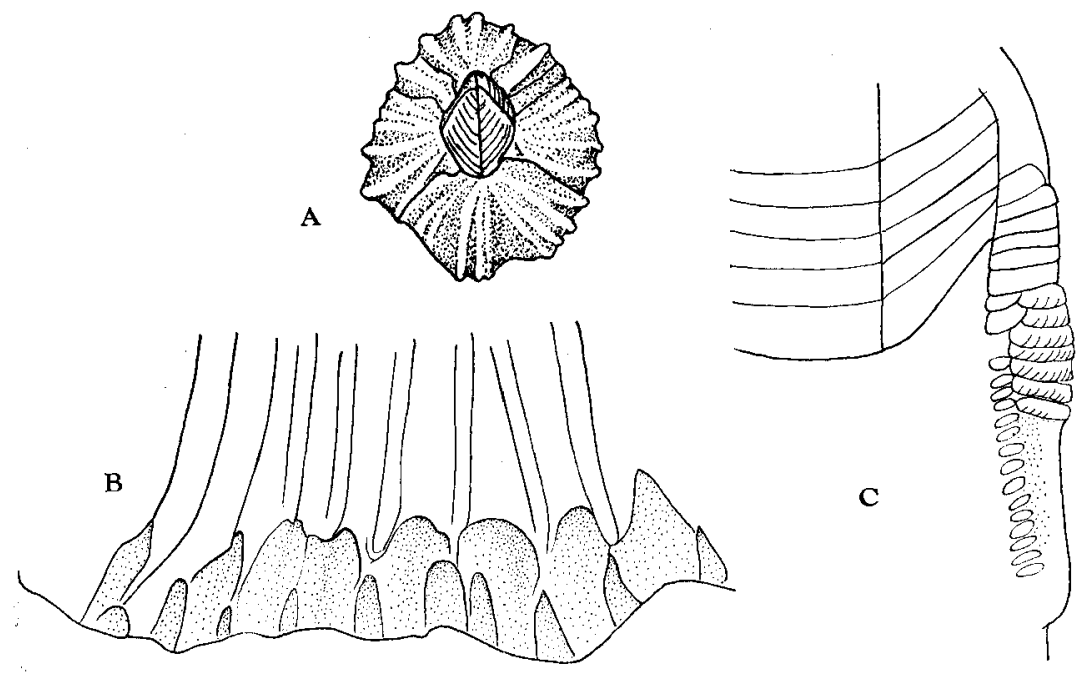

Text-fig. 4. Balanus albicostatus albicostatus Pilsbry from Hatake-zima, Tanabe Bay. A, shell, upper view. B, basal part of lateral compartment, inner view. C, part of rostrum, showing sutural edge, inner view. A, $\times 1.5 ; \mathrm{B}-\mathrm{C}, \times 9$

tergal margin, forming a trinagular lobe and internally is strongly reflexed and rectangularly ended over the broad articular furrow.

The tergum is roughly of equilateral triangle or moderately narrower, with 2 purplish patterns radially running on the flat outside. The spur is short, roundly ended and separated by less than its own width from the basi-scutal angle. The interior is smooth or roughened in the upper part and provided with many crests for the depressor muscles along the straight or slightly concave basal margin, becoming dentate towards the base of the spur.

Habitat: Exclusively on intertidal stones, rocks or moles in quiet inner bays and harbors protected from rough surf. This barnacle is most tolerable to long desiccation like Chthamalus challengeri occurring on high tide levels. 
Distribution: Known only in Japan, Korea and China, northward to Mutu Bay of Honsyu.

Remarks: This barnacle was originally regarded by PILsBRy (1916) as a variety of $B$. amphitrite following the current concept on the variability of the species.

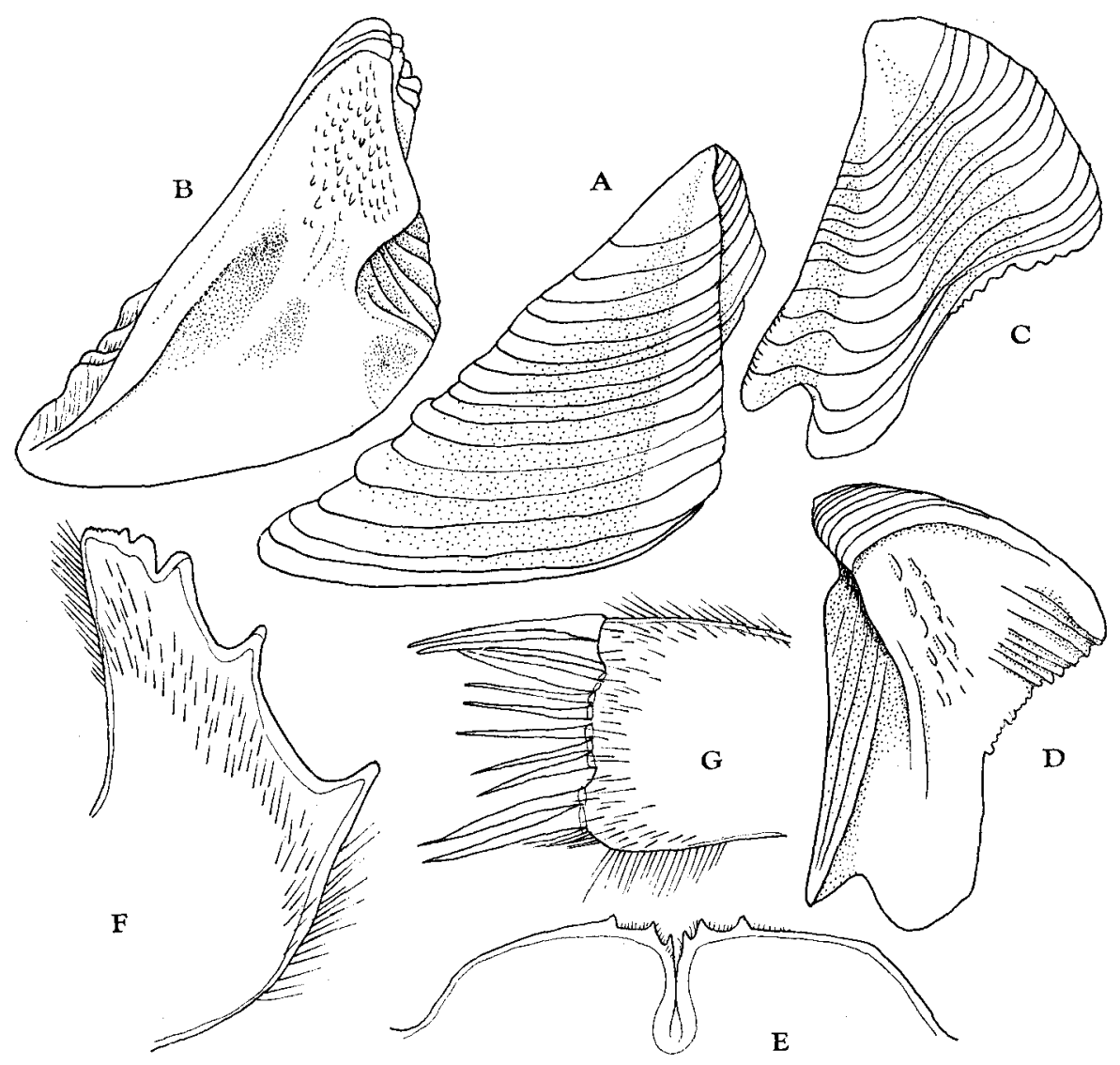

Text-fig. 5. Balanus albicostatus albicostalus Pilsbry from Hatake-zima, Tanabe Bay.

A, scutum, outer view. B, scutum, inner view. C, tergum, outer view. D, tergum, inner view. E, labrum. F, mandible. $G$, first maxilla. A-D, $\times 12$

However, if HARDING's procedure is followed, it must be regarded as a distinct species, somewhat related to $B$. venustus in the shape of the opercular valves and in having 3 pairs of teeth in the labrum rather than $B$. pallidus (including stutsburi) as PILsBry at first thought. But the above-mentioned peculiarity in the parietal tubes of the wall represents to be specifically different. 


\section{Balanus albicostatus formosanus HIRo (emend.) (Japanese name: Taiwan-huzitubo)}

(Text-figs. 6-7 and Plate VI, fig. 3)

B. amphitrite forma formosanus HiRo, 1938, p. 306, figs. 6-7-Rokuko (Luchiang), Gosei (Wuchi) and Tanshui Estuary.

B. a. albicostatus: Hro, 1939, p. 261, fig. 8B-Toi near Kiirun (Kilung), Tanshui, Rokuko (Lu(chiang), Gosei (Wuchi) and Takao (Takou or Kaohsiung) (all of Taiwan).

Not B. a. formosanus: Kolosváry, 1962e, p. 199, fig. 1 (tergum only)-Karakum desert, Caspian Region (fossil).

Syntype: SMBL-Type 21 (specimens from Rokuko, Taiwan) deposited in the museum of the Seto Marine Biological Laboratory.
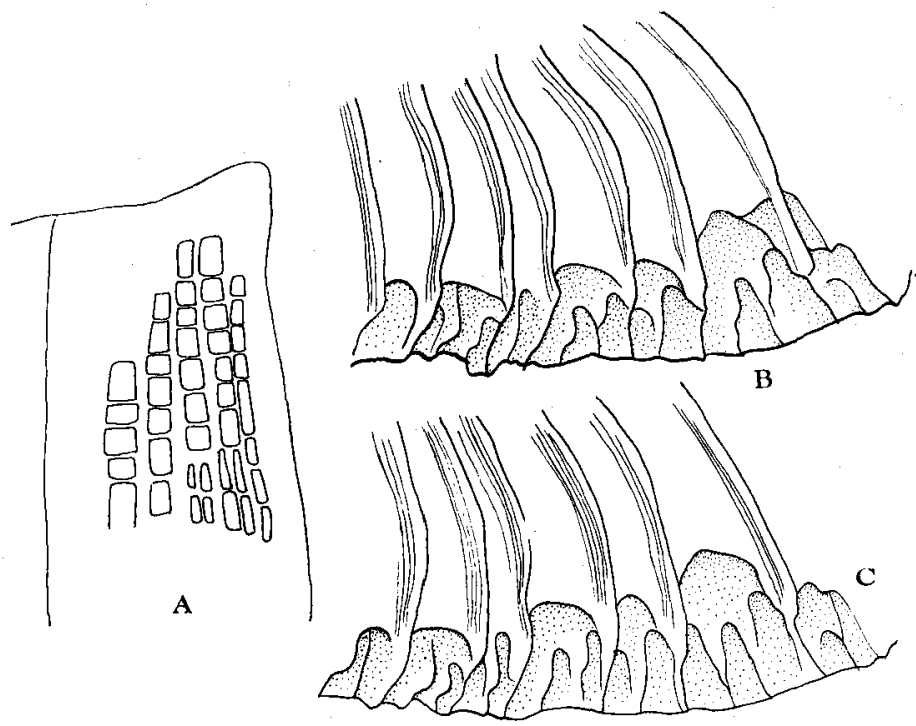

Text-fig. 6. Balanus albicostatus formosanus HiRo from Luchiang, Taiwan. A, upper part of croded lateral compartment, showing parietal tubes with transverse septae, exposed. B-C, basal part of compartments, inner view. All $\times 9$

Material Examined: (1) Luchiang (Syntype-SMBL-Type 21). Coll. Dr. Hayato Sato, 1936. (2) Luchiang. Coll. H. Utinomi, 1938. (3) Wuchi. Coll. Dr. Hayato Sato, 1936. (4) Tanshui Estuary. Coll. Dr. D. Miyadr, 1937 and H. Utinomi, 1938. (5) Takou (Kaohsiung). Coll. H. Utinomi, 1938.

Supplementary Description: The shell of the specimens aggregated on oyster shells is generally tubulo-conical, with a large rhombic orifice. Externally the parietes are nearly smooth, whitish, and marked with barely raised, wide white ribs between which the furrows are wider and evenly dark rose or marked with a 
number of the same colored longitudinal stripes. These barely raised white ribs are never so prominent as in the typical albicostatus and much fewer, when the narrow white stripes between them are not counted.

The radii are broad, purplish, with oblique summits, and their sutural edges are transversely septate.

Internally, the sheath is short, less than one-half of the height and colored dark purple. The face of the inner lamina below the sheath is strongly ribbed all throughout. These inner ribs are flattopped and much fluted on both sides. They continue to the thin longitudinal septa between the parietal tubes, without protruding at their ends, although the basal margin of the inner lamina between these ribs is strongly concave.

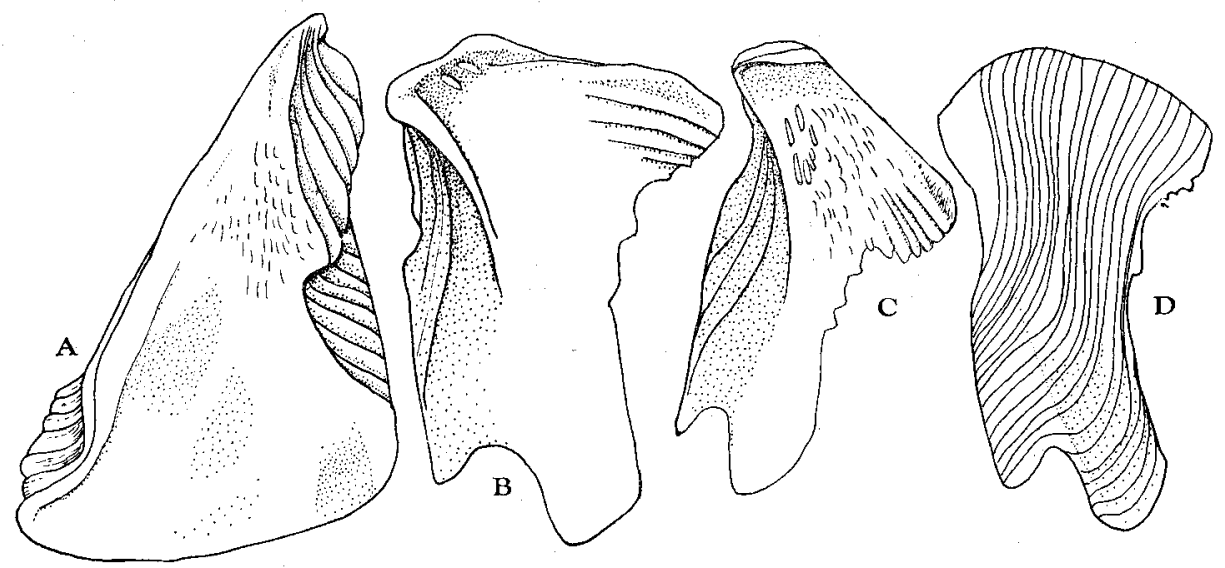

Text-fig. 7. Balanus albicostatus formosanus Hiro from Tanshui, Taiwan.

A, scutum, inner view. B-C, tegum, inner view. D, tergum, outer view. All $\times 12$

The parietal tubes are transversely septate in the upper part of the parietes, as can be seen from outside in much eroded shell. The parietal pores shown at the base of the wall is much more complex than in the preceding albicostatus from Japan, the secondary pores formed close to the basal edge of the wall being intercalated deeply within the primary pores (compare figs. $4 \mathrm{~B}$ and $6 \mathrm{~B}-\mathrm{C}$ ).

The scutum is externally flat, uncolored, with broadly reflexed articular ridge; internally slightly roughened in the upper part. The adductor ridge is widely separated from the lower end of the articular ridge and rather low, while the depression for the adductor muscle is deep and elongated in parallel to the occludent ridge; the pit for the lateral depressor muscle is distinct or obsolete.

The tergum is externally flat, rather narrow and long; internally deeply sunken from the articular ridge and roughened with many tubercles. The spur is rather long, slightly tapering to the obliquely truncated end and is well away from the basi-scutal angle. The basal margin, often confluent with the carinal margin of the 
spur, is slightly concave towards the basi-carinal prolongation which bears internally about 5 crests for the depressor muscles and some obtuse teeth along the basal concavity.

Habitat: Aggregated on wharf piles, rock-oysters on protected coasts or ports where are exposed during low tides.

Distribution: Hitherto known only from the north and west coasts of Taiwan (Formosa).

Remarks: This form was originally described by myself (HrRo, 1938) as a local form of $B$. amphitrite in the broad sense, related to the Japanese form albicostatus PilsBry, but later (HrRo, 1939) merged to the latter, considering the latter a subspecies. Now, from the alleged close relationship this Formosan form should be treated as a subspecies of $B$. albicostatus raised to the specific rank. The intralaminate figure of both forms is similar and quite different from that of the other smooth-walled species with one-layered parietal pores.

\section{Balanus variegatus cirratus DARWIN (Japanese name: Amime-huzitubo)}

(Text-fig. 8)

B. amphitrite var. (9) cirratus DARwin, 1854, p. 241, pl. 5, fig. 2b-Mouth of Indus, Australia and Philippines.

B. a. cirratus: Nilsson-CANTELl, 1921, p. 316, fig. 65-Hongkong and Sunda Is. (on mangroveroots); Nilsson-Cantell, 1931, p. 111 -Santuao, Fokien of South China (on shells); NiLssonCantell, 1934b, p. 56-Batavia (on shells); Nilsson-Cantell, 1938b, p. 40 -Orissa coasts, etc. of India (on shells and wood); Hiro, 1938, p. 302, fig. 2-Iki Is., Ariake Sound, west coast of Korea, Takou (Taiwan); Hтro, 1939, p. 262-Rokuko (Luchiang), Anping and Takou (Kaohsiung); Utrnomi, 1949, p. 22-Iki Is. (on bamboo) and Misumi (on gastropod shells); Utinomi, 1962, p. 216-Nomosaki (on angler-ropes); Zevina and Tarasov, 1963, p. 89, fig. 10-Lüta, Yantai, Tsingtao, Chau Chwang and Hainan Is.

B. variegatus var. cirratus: HARDING, 1962, p. 293, pl. 10, figs. 1-0-Mouth of Indus (on gastropod shell).

? B. a. vladivoskensis TARAsov and Zevina, 1957, p. 184, fig. 67-Vladivostok.

Not B. a. cirratus: Pope, 1945, p. 362, pl. 28, figs. 5-6 and pl. 29, fig 6 and pl. 30, figs. 13-14-Port Jackson, Australia $[=B$. variegatus variegatus DARwiN].

Not $B$. variegatus var. cirratus: Pope, 1966 , p. $179-$ Port Phillip Bay, Australia $[=B$. variegatus variegatus DARWIN].

Lectotype: B.M. 1961.61. 12. 6. 82 G (from Mouth of Indus) deposited in the British Museum (Nat. Hist.), London.

Material Examined: (1) Takou (Kaosiung), Taiwan. Attached to small bivalve shells Aloides flava. Coll. Mr. Ai Yamaguchr. (2) Takou Port, Taiwan. Attached to submerged wracks at the Hagihara Dockyard. Coll. H. Utinomi, 1938. (3) Anping Port, Taiwan. From wooden ships foulings. Coll. H. Utrnomi, 1938.

(4) Misumi, mouth of Ariake Sound, Kyusyu. Attached to shells of a gastropod 
Rapana thomasiana taken at low tide. Coll. H. Utinomi, 1936. (5) Pyengyang Fish Market, North Korea. Attached to the carapace of a crab Orithyia sinica. Coll. Dr. T. Kamita, 1934.

Supplementary Description: The shell is conical or tubulo-conical, with a large, rhombic orifice, moderately toothed around the apex.

The parietes are quite smooth, whitish buff in ground color and marked with narrow, light purplish brown longitudinal stripes which are intersected by horizontal

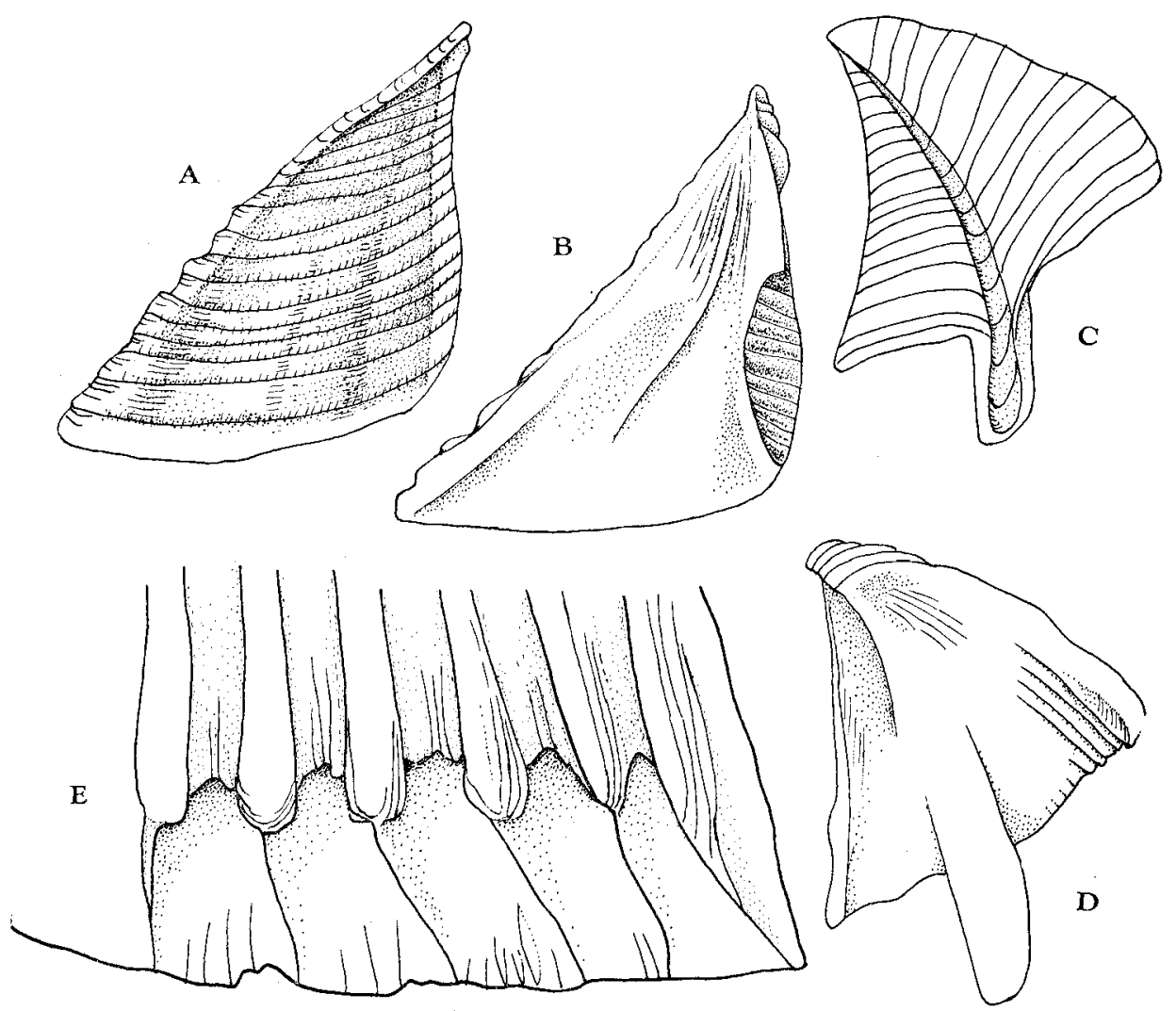

Text-fig. 8. Balanus variegatus cirratus DARwin from Takou, Taiwan.

A, scutum, outer view. B, scutum, inner view. C, tergum, outer view. D, tergum, inner view. E, basal part of lateral compartment, inner view. All $\times 12$

bands of the same color, both being equidistantly spaced. The radii are broad, uniformly whitish buff, with oblique summits. Their sutural edges are transversely septate. Internally, the sheath occupies more than one-half of the height of the parietes, and below it the face of the inner lamina is strongly ribbed. These ribs are rather low, fluted on both sides and protruding below just before continuing to the narrow longitudinal septa between the parietal tubes. The parietal tubes are 
arranged in one row and their basal openings are broad and rectangular in outline and further a few small secondary riblets (about 1-5 per pore, approximately $1 \mathrm{~mm}$ wide) and many denticles are intercalated between the primary septa along the basal margin of the outer lamina.

The scutum is concave externally with a pink or purplish brown pattern in the middle; the growth-lines are prominent and minutely beaded along which the persistent overlying epidermis is hairy; internally the articular ridge is high but weakly reflexed; the adductor ridge is distinctly away from the articular ridge by a deep pit inserted between; the pit for the lateral depressor muscle is distinct.

The tergum is approximately equilateral-triangular, with a narrow long spur lying in midway of the straight basal margin, right-angled. Externally a narrow, semi-open furrow runs from the apex to the end of the spur; internally there are 4 short but prominent crests for the carinal depressor muscles.

Size. One of the largest specimens here examined in the isolated condition measures as follows: Carino-rostral diameter $20 \mathrm{~mm}$, height $11 \mathrm{~mm}$, greatest orificial diameter $11 \mathrm{~mm}$.

Habitat: Usually attached to intertidal or upper subtidal molluscan shells and other benthic animals living on sandy botton.

Distribution: Hitherto known with certainty from Australia, northern coasts of the Indian Ocean, Malay Archipelago, Singapore, Philippines, Taiwan (Formosa), China and west coasts of Kyusyu and Korea, not extending eastwards along the Pacific coast of Japan.

Remarks: Harding (1962), after re-examining Darwin's material in the light of modern usage of nomenclature, has raised Darwin's var. variegatus to the specific rank and treated this cirratus as a variety within it. This procedure seems to be reasonable morphologically. But now I treat it as a subspecies, as done for the varieties or subspecies closely allied to $B$. venustus s. str. No further discussion may be needed.

\section{Balanus reticulatus Utinomi, nom. nov. (Japanese name: Sarasa-huzitubo)}

(Text-figs. 9-12 and Plate VI, figs. 7-8)

B. amphitrite var. (1) communis DARwiN, 1854, p. 240, pl. 5, figs. $2 e, 2 h$ and $2 l$ (partim).

? B. a. var. (1) communis: HoEk, 1913, p. 168, pl. 14, figs. 12, 14* and 16-Siboga St. 2, Madura Strait, $56 \mathrm{~m}$; Batavia (on bambusa).

Not B. a. communis: Nilsson-Canteli, 1921, p. 311, fig. 64-Mindanao, Biliton and Java Sea (on mangrove roots and barks) [=B. amphitrite amphitrite DARwin sensu HARding]

B. a. forma communis: Broch, 1922, p. 314-Manila Bay, 5 fms. and off Jolo, 20-30 fms.; Broch, 1931, p. 58-Lampong Bay, 25 m, Gulf of Siam, $12 \mathrm{~m}$, Sound at Koh Chang, 6-10 m.

Not B. a.comminis: Nilsson-Cantell, 1931, pp. 110, 122, fig. 3-Mediterranean Sea (on molluscan 
shells) and Cape of Good Hope (on woods); Nilsson-Cantell, 1938b, p. 36, fig. 7-Portuguese East Africa and various localities of India.

B. a. communis: Hrro, 1938, p. 301, fig. 1-various localities of Japan.

? B. a. communis: Kolosváry, 1939, p. 129, figs. 1-65 (account on variation of opercular valves, cited from various resources).

B. a. communis: Utinomi, 1956, p. 52, pl. 26, fig. 11 (colored); Uтіnomi, 1960, p. 44, figs. 1c, 1d, $2 c$ and $2 d$ (comparison with $B$. hawaïensis BRoch (=B. amphitrite amphitrite D.); Stubbings, 1961a, p. 173 -Persian Gulf (on oyster-shells from piers); Stubbings, 1961c, p. 205, figs. 3, 6, 9 and 13-fossils from Kaspi and Aral Neogene.

B. a. variety: Southward and CRISP, 1963, p. 43, fig. 23 (colored)-West Indies (on oyster).

B. a. tesselatus Utinomi (nom. nov.), 1964, p. 52, pl. 26, fig. 11 (colored).

B. variegatus tesselatus Uтіломг (nom. nov.), 1966, p. 5 (listed only)-Tomioka and Nomosaki, Kyusyu. Not B. tessellatus Sowerby, 1818, Mineral Conchol., pl. 84 [=Balanus balanus (Linné, 1758)].

Lectotype (Pl. VI, figs. 7-8): A complete typical specimen selected from many specimens taken from test panels suspended at a depth of $5 \mathbf{m}$ at Tatigatani, Tanabe Bay, Wakayama Pref., Japan. Coll. H. Utinomi, 3 June, 1934. Deposited in the muscum of the Seto Marine Biological Laboratory, registering as SMBL-Type 199.

Size of lectotype. Carino-rostral diameter $26 \mathrm{~mm}$, height $15 \mathrm{~mm}$, greatest orificial diameter $10 \mathrm{~mm}$.

Material Examined: (1) Tatigatani, Tanabe Bay, Wakayama-ken, Japan. Many specimens attached to test slate panels or cultured oysters suspended from rafts at various depths. Coll. 1934 1965. (2) Ago Bay, Mie-ken, Japan. Many specimens attached to test panels for fouling organisms. Coll. Dr. Shizuo Mawatari, 1952 and Dr. Tatuo Kawahara, 1958.

Supplementary Description (Also see Hiro, 1938, p. 301 and Utinomi, 1960, p. 47): The shell is typically conical, with a comparatively small, rhomboidal orifice, strongly toothed around, when isolated. So the base often tends to conspicuously expand relatively to its height. The apex of all compartments, especially the carina, is often turned outwards, thus showing a concave profil in lateral aspects.

The ground color of the shell is reddish gray, darkened with bluish tint in the upper part, and the parietes are externally quite smooth, polished and ornamented with rather broad dark purple longitudinal stripes equidistantly which are intersected by many narrower reddish brown and white horizontal lines alternately.

The radii are narrow, with very oblique summits; they are generally white, freckled with reddish brown spots. The sutural edges are transversely septate, each septum being denticulate downwards.

Internally, the sheath is broad, nearly one-half as long as the paries, and its lowest part is quite smooth, lacking transverse striations, and its basal edge is not free from the inner face of the wall. The inner lamina below the sheath is rather weakly ribbed. These inner ribs do not protrude at the bottom of the inner lamina, although slightly denticulate on both sides at the transition to the thin longitudinal septa connecting both the inner and outer laminae.

The parietal tubes are arranged in one row and devoid of any transverse septa 


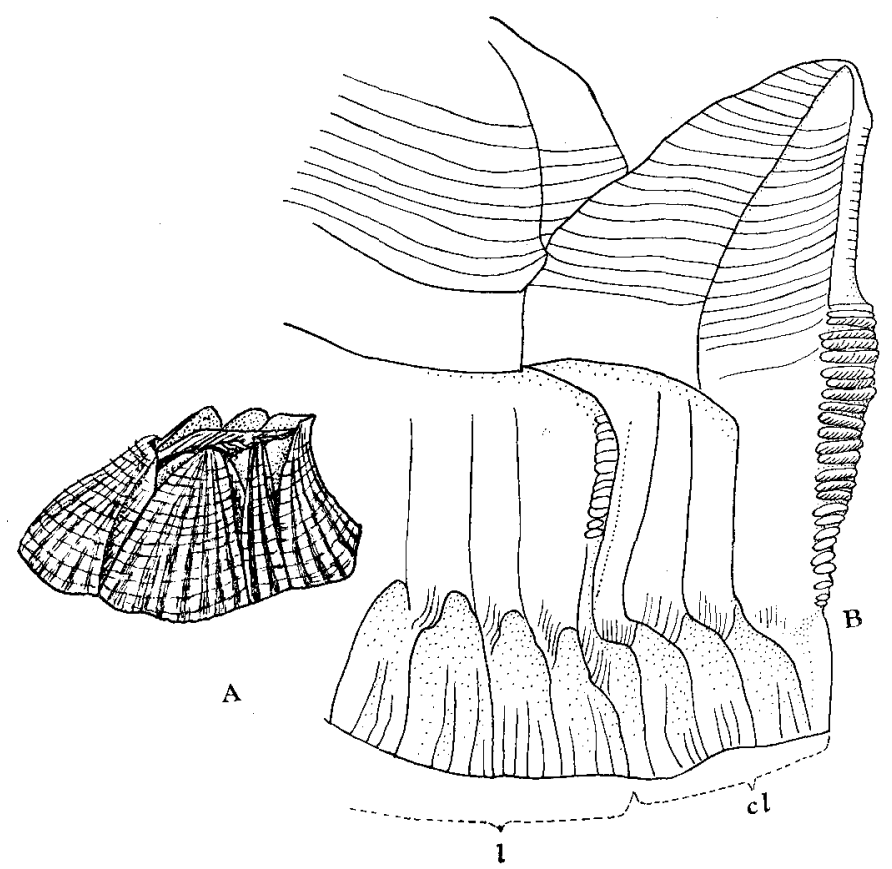

Text-fig. 9. Balanus reticulatus Uтімом, nom. nov. from Tatigatani, Tanabe Bay.

A, shell, side view. B, carino-lateral $(c l)$ and lateral $(l)$ compartments connected together, inner view. A, $\times 1.3 ; \mathrm{B}, \times 9$
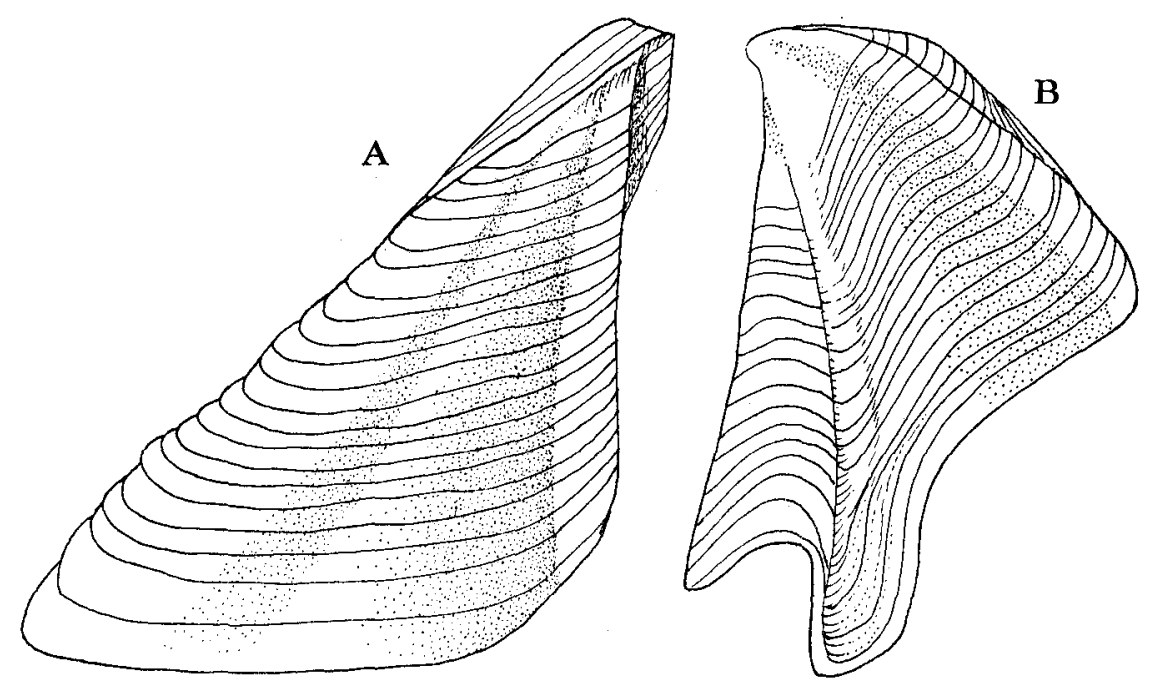

Text-fig. 10. Balanus reticulatus UTINomi, nom. nov. from Tatigatani, Tanabe Bay. A, scutum, outer view. B, tergum, outer view. All $\times 12$ 
up to the tip of the wall. Basally, their openings are eonsiderably large and radially elongated rectangular in section, and many incomplete septa or riblets are present on the inner face of the outer lamina. Apparently these subsidiary septa are elevated on the wall apart from the basal margin, thus they may not serve as the "teeth" locking the calcareous basis.

The scutum is flat externally and colored dull purple in the middle. Internally, the articular ridge is prominent, about one-half of the tergal margin and the adductor ridge is rather low and short; the pit for the lateral depressor muscle is more or less obscurely defined.

The tergum is externally almost flat, with a very shallow spur fasciole; the basal

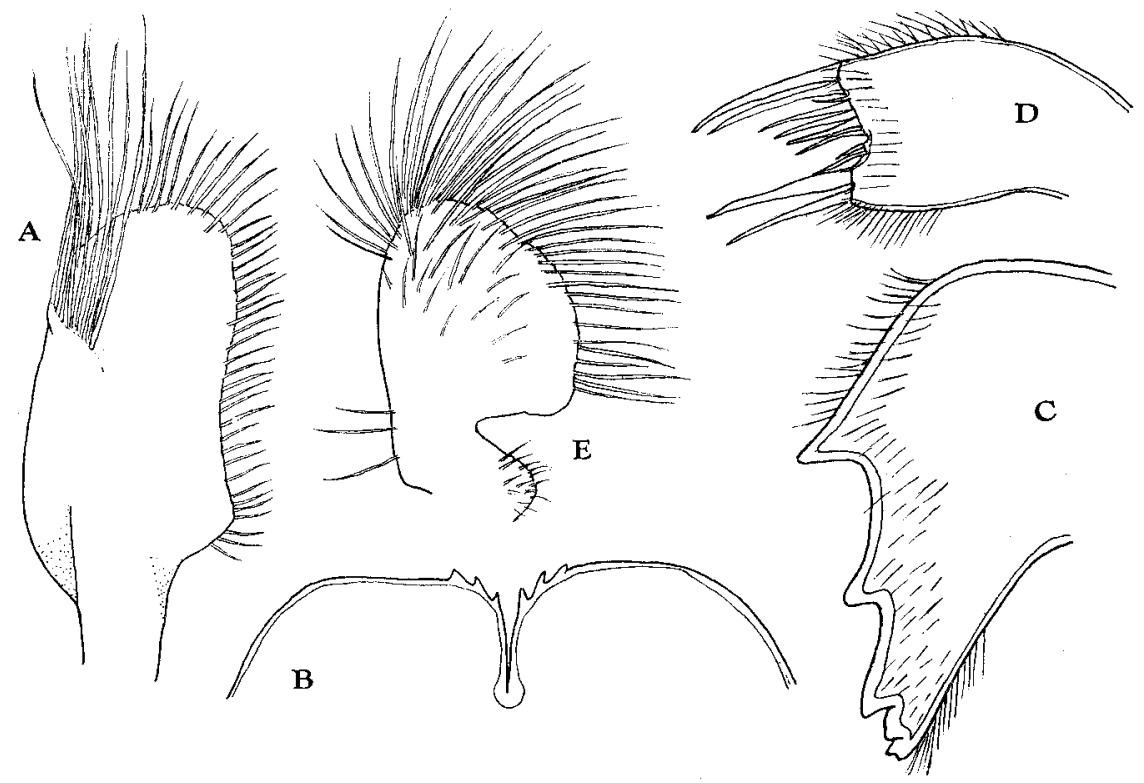

Text-fig. 11. Balanus reticulatus UTrNom, nom. nov. from Tatigatani, Tanabe Bay. A, palp. B, labrum. C, mandible. D, first maxilla. E, second maxilla.

margin is straight, a little longer than the slightly convex carinal margin. The spur itself is rather short, narrow and obliquely truncated at the end; it is approximately its own width distant from the basi-scutal angle and right-angled to the basal margin. The crests for the depressor muscles are not so strong and mostly $5-7$ in number.

Mouthparts. - The labrum has invariably 3 teeth on each side of the median notch. The mandible has 3 main teeth and a tripartite lower angle. The first maxilla has 2 large upper, 7 smaller middle and 2 largest lower spines along the frontal margin, of which the lowest angle bearing 2 largest spines is strongly protuberant.

Cirri.-As usual in the Balanus amphitrite complex, the first cirrus has unequal rami. 
The second and third cirri are equally short in both rami. In the third cirrus, each segment is very short, broad and thickly set with conical spinules and many setae along the frontal border. Of the posterior longer cirri the intermediate segment bears 6 pairs of large setae and one pair of subsidiary small setae between each pair of large ones.

Habitat: Apparently confined to the upper subtidal area, about $2-10 \mathrm{~m}$ in depth (most abundant at $5 \mathrm{~m}$ deep) and dominated in highly saline bay waters faced to open sea (most abundant between 18.36-18.57 o/oo Cl.). Larval settlement begins late in April and continues until early November but large number of settled juveniles is from June to August, according to cumulative data of fouling tests made

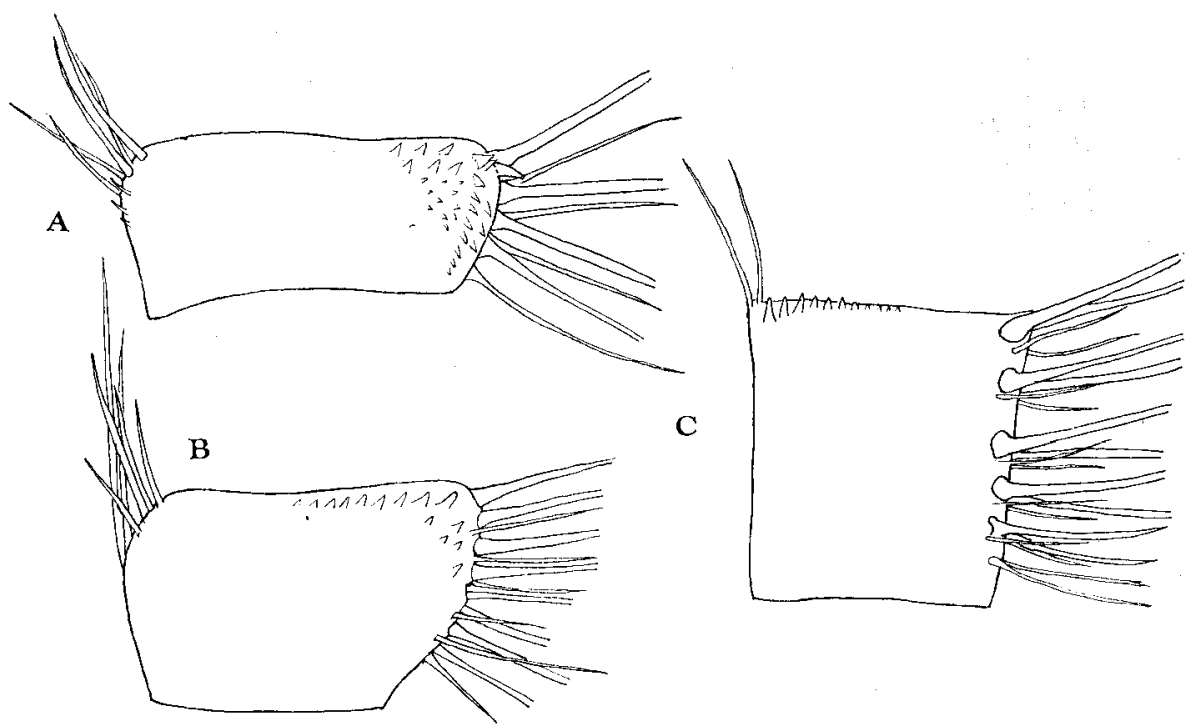

Text-fig. 12. Balanus reticulatus UтіNoм, nom. nov. from Tatigatani, Tanabe Bay.

A, 7 th segment of cirrus III. B, 11 th segment of cirrus III. C, intermediate segment of cirrus $\mathrm{V}$.

in Ago Bay, Mie-ken, Japan, by Mawatari et al. (1954) and Kawahara and Irjima (1960).

Distribution: Although indefinitely known due to the confused determination made by earlier authors, this barnacle may probably be widely distributed in all seas of the world and transported by ships. In Japanese waters I formerly recorded from many localities: northerly Ominato Port (Mutu Bay) south to Isigaki-zima (Ryukyu Is.) (Hrro, 1938). Nowadays it seems to be less predominant than Balanus amphitrite amphitrite $(=B$. a. hawaiiensis $)$ in many bays or harbours.

Remarks: As mentioned above (p. 201), this presumably widely distributed barnacle has long been confused with Balanus amphitrite hawaiiensis or $B$. a. denticulata., 
both established by Broch much later than the period of Darwin. Both Broch's subspecies of $B$. amphitrite have numerous teeth on the labrum.

Concerning this problem, we must point out many obscurities of Darwis's original definition for the species B. amphitrite and its varieties. For example, he gives the diagnoses as follows:-

Balanus amphitrite- - Shell longitudinally striped with purple or pink; sometimes with the stripes confluent: sometimes wholly white. Scutum internally with a prominent broad adductor ridge.

Var. (1) communis_-Nearly white, with pale or dark violet-colored longitudinal stripes; epidermis rarely persistent; shell either thin or thick; radii white or freckled with reddish mahogany colour, with their summits either oblique, sometimes in a high degree, or nearly parallel to the basis; basal point of spur of the tergum either square or bluntly pointed. (italic is mine)

And for the mouthparts, he mentions as specific (not either of the varieties) characters as follows:

Labrum, with from four to eight, generally six, little teeth: mandibles with three teeth and two minute lower teeth, or mere knobs: maxilla with the edge straight, or with the inferior part forming a slightly step-formed projection. (italic is mine)

Next, as seen in Darwin's Pl. V, figs. $2 e$ (lateral aspect of shell, colored), $2 h$ (interior of scutum) and $2 l$ (exterior of tergum) exactly agree with figs. $9 \mathrm{~A}, 10 \mathrm{~A}$ and $10 \mathrm{~B}$ of Balanus reticulatus which I propose herein to rename, and by no means correspond to HaRding's Pl. I, figs. $a, c$ and $f$ of the lectotype of Balanus amphitrite that he selected from Darwis's materials still exist in the British Museum. Unfortunately, no mention for these doubtful points was given by HARDing at all. Supposedly the materials figured by DARwIN as "var. communis" might had been lost at all.

As for the diagnostic characters used to separate the subspecies of Balanus amphitrite complex, Harding emphasizes that the tergum is of greater diagnostic value than the scutum, while the labrum is very variable, so that of little further value. As to this point $I$ am as before against his view. Indeed, $B$. amphitrite sensu Harding (syn.: B. a. hawaïensis, B. a. denticulata, B. a. franciscanus, B. herzi and B. a. saltonensis) has a multidenticulate labrum. $B$. uliginosus $(=B$. a. krügeri $)$ has invariably 4 teeth on each side of the notch in the labrum. In B. albicostatus, B. pallidus, B. venustus (incl. alleged subspecies), $B$. variegatus (incl. alleged subspecies) and $B$. reticulatus here renamed, have normally 3 teeth on each side of the notch, exceptionally 2 teeth on one side only. In B. peruvianus described by Pilsbry $(1909,1916)$ from mangrove swamp in Peru, the labrum is said to have only 2 teeth on each side of the notch.

Of the earlier eminent cirripedologists, apparently Nilsson-Cantell (1921, 1931 and 1938) seems to have referred the multidenticulate form to DarwiN's var. communis, while Broch (1922 and 1931) seems to have three-denticulate form referred to communis.

Apart from the essential disparity in the denticulation of the labrum, many of the specifically important differences in the morphological details and habitat cannot be denied, as formerly enumerated (cf. UTinomi, 1960, p. 47, Table 2).

In any way, it should be advisable to divide Balanus amphitrite communis in Dar- 
winian sense into two separate specific ranks. When renaming this reticularly striped form with three-denticulate labrum, I have provisionally given the substitute name tesselatus for it (Utinomi, 1964 and 1966). To my regret, I was quite unaware of the homonymy of the latter at that time. The name tesselatus is in any case inadmissible as it is preoccupied by Balanus tessellatus Sowerby, "Mineral Conchology", 1818, Pl. 84, which is a synonym of a different species-B. balanus (LinNÉ, 1758). I, therefore, select one of the "communis"-like specimens from Tanabe Bay at hand, not in the sense of HARDING (1962) as the type and rename it herein Balanus reticulatus, ranking at a specific level.

8. Acasta spinifera Utinomi, spec. nov.

(New Japanese name: Igaguri-kaimenhuzitubo)

(Text-figs. 13-16 and Plate VI, figs. 9-11)

Material Examined: 6 complete specimens imbedded in a silicious sponge Phakellia foliacea THIELE, forming gall-like elevations on the upper surface of foliate branch. Off Mera, Tiba-ken, mouth of Tokyo Bay, $70 \mathrm{~m}$ deep. Coll. Dr. Minoru Imajima (National Science Museum, Tokyo) and sent me by Miss Yasuyo Kawashima (Research Institute for Natural Resources, Tokyo) for determination.

Types. Holotype (Text-fig. 13 and Pl. VI, fig. 9), registered as SMBL-Type 202. 2 paratypes A and B, registered as SMBL-Type 203. Both are deposited in the museum of the Seto Marine Biological Laboratory. They measure as follows:

$\begin{array}{lcc} & \text { Carino-rostral diameter } & \text { Height } \\ \text { Holotype } & 6.0 \mathrm{~mm} & 7.0 \mathrm{~mm} \\ \text { Paratype A } & 4.5 & 5.0 \\ \text { Paratype B } & 8.0 & 9.0\end{array}$

Description: The shell is rather fragile, reddish white, especially the upper part of parietes and all radii and alae. The orifice is broad, as large as the basis and strongly toothed. The basis is quite flat, calcareous, very thin, non-porous, smooth inside but concentrically ringed outside.

The compartments are well developed, adjoining each other basally. The parietes are solid, externally studded with solid, upturned spines in longitudinal rows or somewhat irregularly. These outer spines are mostly up to $1 \mathrm{~mm}$ long (though decreasing upwards in length), obtusely pointed, but often forked at tip.

The carino-lateral paries is the narrowest, about $1 / 3$ as wide as the carinal and lateral paries and about $1 / 5$ as wide as the rostral paries, as shown in the following measurements in millimeters:

$$
\text { Paratype A }\left\{\begin{array}{ccccc} 
& \text { G } & \text { CL } & \text { L } & \text { R } \\
\text { Width } & 2.5 & 0.8 & 2.5 & 3.0 \\
\text { Length } & 6.0 & 4.5 & 5.0 & 5.0
\end{array}\right.
$$




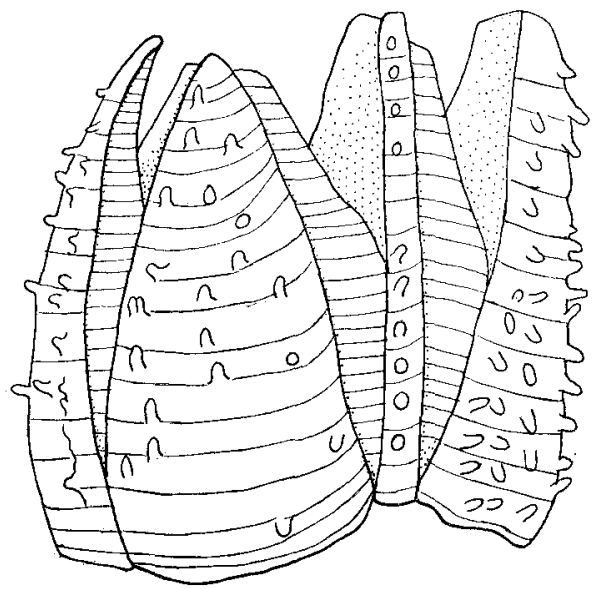

Text-fig. 13. Acasta spinifera Uтімомі, spec. nov. Holotype, side view. $\times 9$
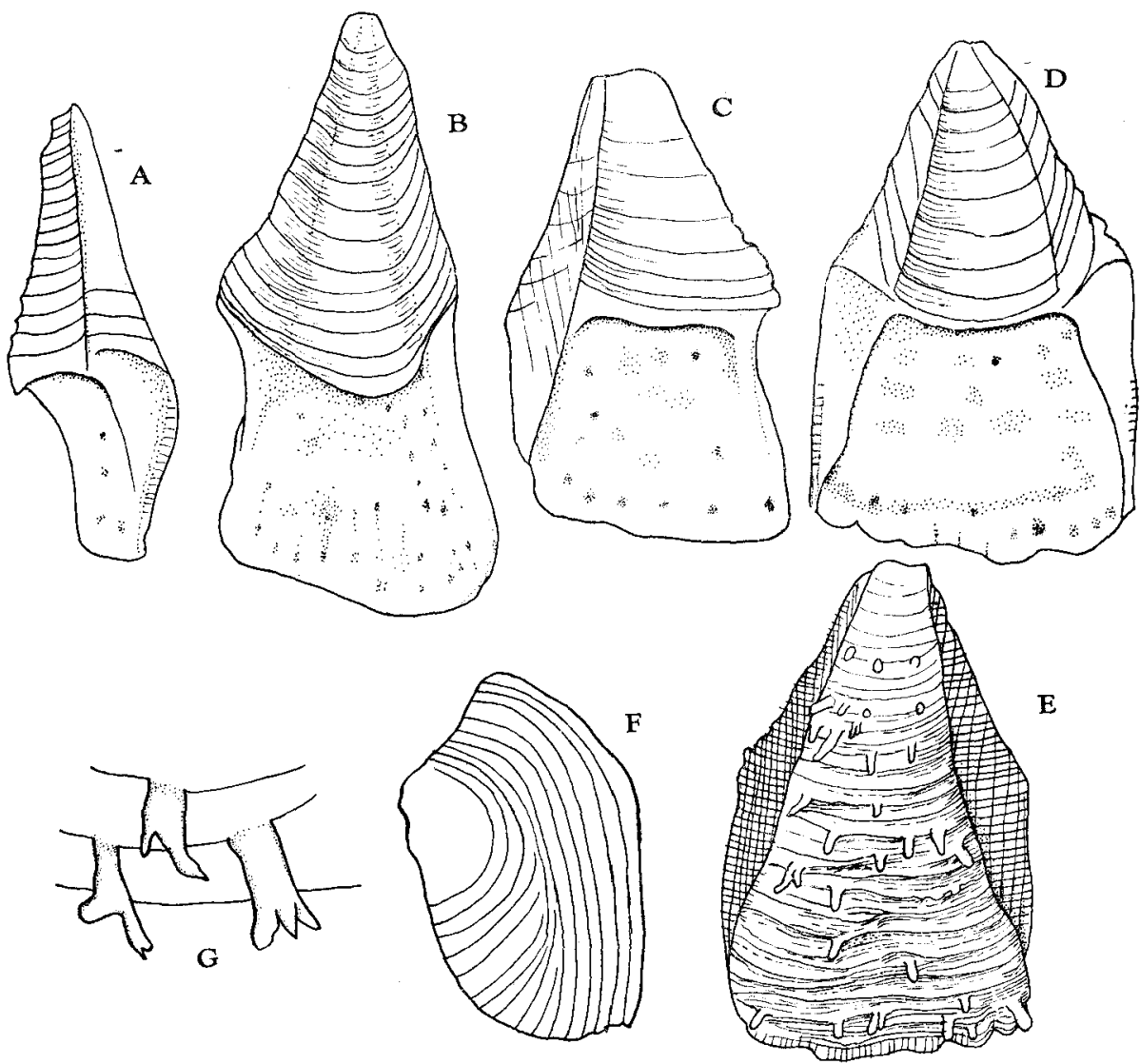

Text-fig. 14. Acasta spinifera UTinomi, spec. nov. Paratype A.

A, carino-lateral compartment, inner view. B, carina, inner view. C, lateral compartment, inner view. D, rostrum, inner view. E, rostrum, outer view. F, part of basis, outer view. $\mathrm{G}$, forked spines. A-F, $\times 12 ; \mathrm{G}, \times 14$ 


$$
\text { Paratype B }\left\{\begin{array}{lllll}
\text { Width } & 4.8 & 1.0 & 4.0 & 5.0 \\
\text { Length } & 8.0 & 7.0 & 8.2 & 9.0
\end{array}\right.
$$

Internally, the sheath in all parietes is broad, occupying the upper half of the height and transversely striated rather coarsely and its lower edge is free from the wall. The inner face below the sheath is not ribbed but scatteredly pitted at the position of the outer spines.

The radii and alae are very broad, with obliquely sloping upper edges and transversely striated; all sutural edges are minutely septate.

Opercular valves.-The scutum is moderately thick, higher than wide and sculptured with strong radial ridges crossed on the growth-lines along which the overlying yellowish epidermis is hairy. Internally, the articular ridge is prominent, longly curved over the broad articular furrow; apparently there is no distinct depression for the adductor and lateral depressor muscles.

The tergum is triangular, about as long as wide, with a beaked apex and a short spur; the exterior is quite flat, marked with smooth growth-lines widely spaced and fringed with hairs; there is a prominent open furrow running from the apex to the obliquely truncated end of the spur which is distant from the basi-scutal angle by about one-half its own width, forming a right angle. Internally, the articular furrow is very wide and no crests for the depressor muscles.

The cirri in the paratype specimen B dissected show the following numbers of segments :

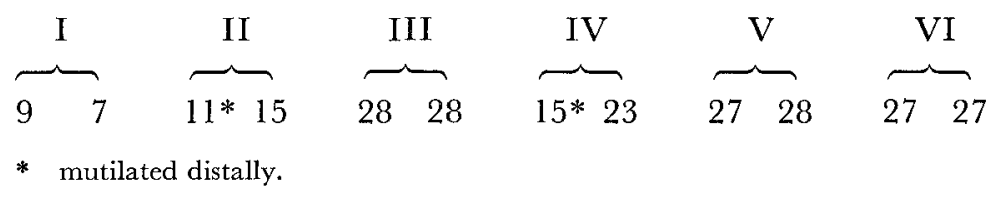

In cirrus $I$, the anterior ramus is a little longer than the posterior. In cirri II and III, both rami are subequal. In cirrus IV, neither hooks nor spinules are present on segments of both rami, as in the posterior pairs of cirri V and VI, and only furnished with three pairs of setae on the frontal convex margin and a tuft of 1-3 shorter setae at the dorso-distal corner.

The penis is long, annulated all throughout, but devoid of hairs and basi-dorsal point.

Mouthparts.-The labrum has only 2 denticles on each side of the median notch. The palp is elongate, spoon-shaped and profusely setose. The mandible has 5 teeth and a shortly pointed lower angle. The first maxilla has 2 large upper spines followed by 5 smaller spines in the middle part and 2 larger spines in the lower part along the almost straight frontal margin, terminating by a tuft of a few spinules. The second maxilla is bilobed, the upper lobe being elongate and the lower lobe small and oval, both densely setose along the inner margin. 


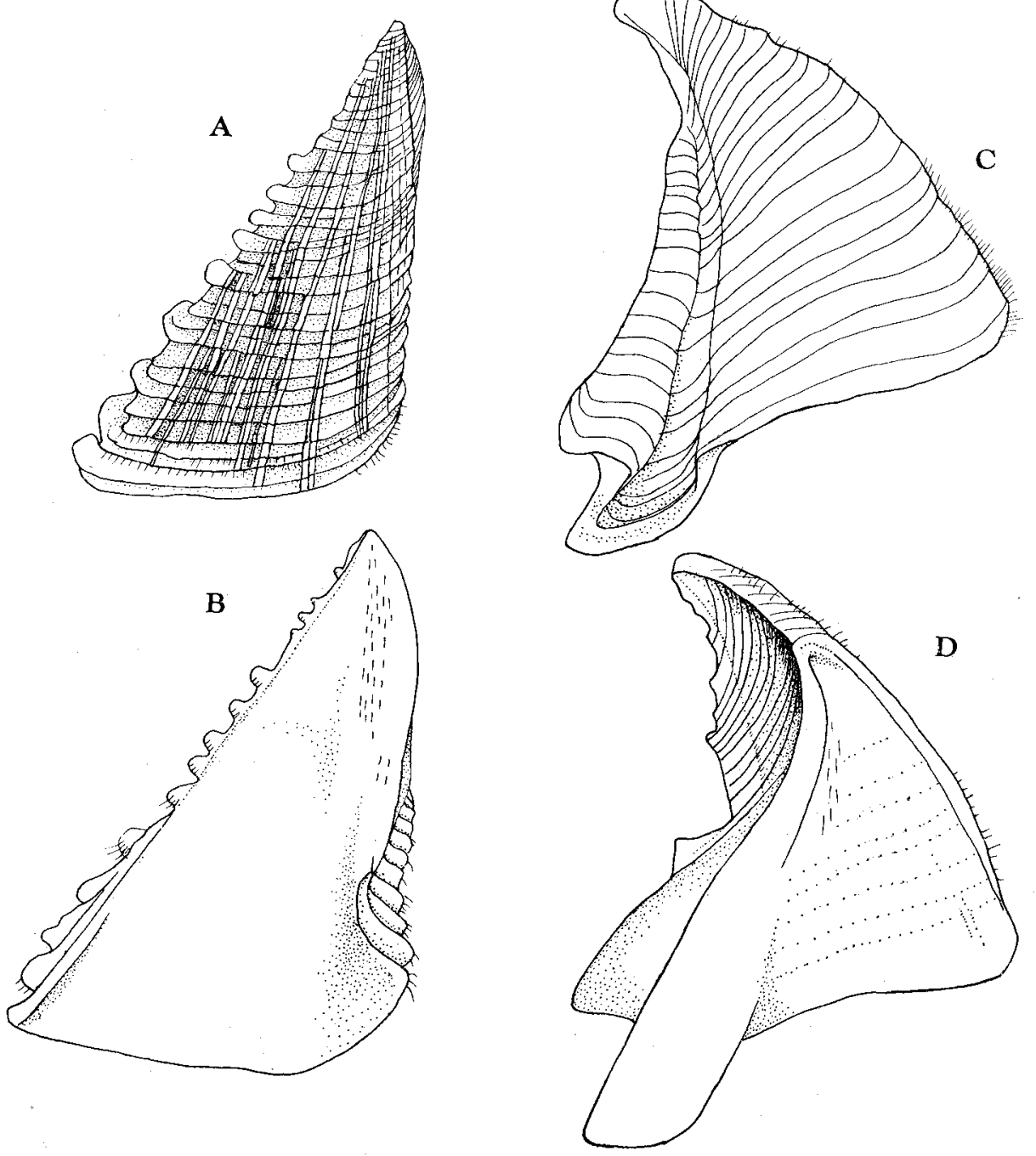

Text-fig. 15. Acasta spinifera Utinomi, spec. nov. Paratype B.

A, scutum, outer view. B, scutum, inner view. C, tergum, outer view. D, tergum, inner view. All $\times 10$

Remarks: In external appearance, this barnacle seems to be most closely allied to Acasta cyathus DaRwin hitherto known from Madeira, West Indies, Florida and (?) the Gulf of Manaar, India and also to Acasta scuticosta Weltner (1887) known only from Cartagena, Spain in the shape of the opercular valves, but evidently different from both in the details of of peculiar structure described and illustrated above.

The absence of hooks or spinules in the fourth cirri in this species shows to be an aberrant form belonging to BROCH's "Inarmata group". 


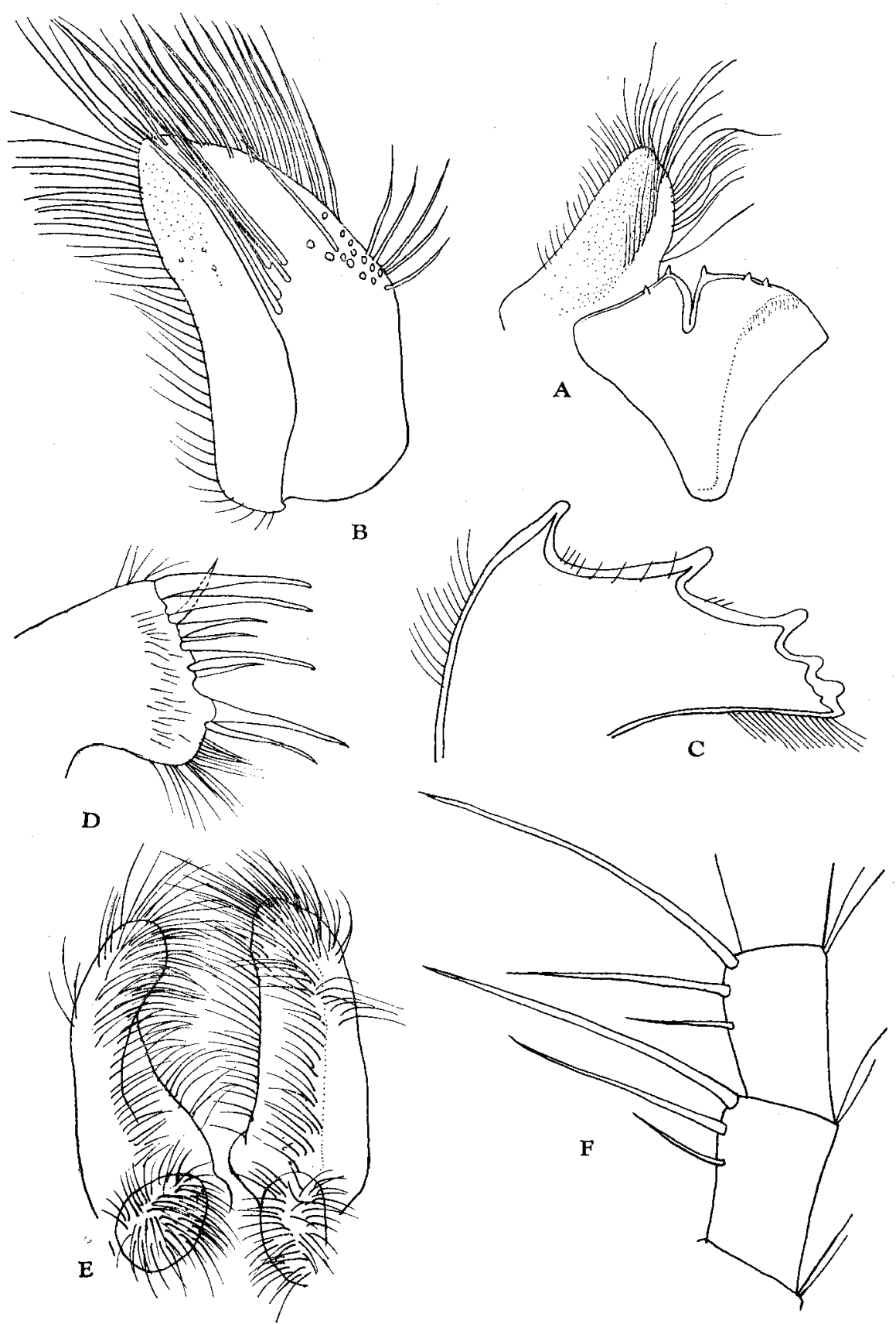

Text-fig. 16. Acasta spinifera Utinomi, spec. nov. Paratype B.

A, labrum and palp. B, palp. C, mandible. D, first maxilla. E, second maxillae. $\mathrm{F}$, iatermediate segments of posterior ramus of cirrus IV. A, $\times 67 ; \mathrm{B}-\mathrm{E}, \times 63 ; \mathrm{F}, \times 97$ 


\title{
9. Creusia indica (ANNANDAle)
}

\section{(Japanese name: Hosi-sangohuzitubo)}

(Text-figs. 17-18 and Plate VI, figs. 12-16)

\author{
Creusia spinulosa LEACH, var. (11) DARwin, 1854, p. 381, pl. 14, figs. $6 U$ and $6 u$-Singapore. \\ ? Creusia spinulosa var. (11): HoEk, 1913, p. 265-Siboga St. 257. \\ Creusia spinulosa LEACH forma angustiradiata BROGH, 1931, p. 118-Kei Islands. \\ Pyrgoma indicum Annandale, 1924, p. 64, pl. 12, fig. 10-Mergui Archipelago. \\ Creusia spinulosa LeAch forma angustiradiata: Nilsson-Cantell, 1938b, p. 62, pl. 3, fig. 1 and text- \\ fig. 23-Mergui Arch.; Hrro, 1935, p. 51, fig. 3-Tanabe Bay; Hiro, 1938b, p. 399-Palao; \\ Uтіломі, 1943, p. 16, figs. 1-4 (larval stages) - Tanabe Bay. \\ Pyrgoma indicum: UTinomr, 1962, p. 227-Nomosaki. \\ Creusia indica: Uтімомп, 1966, p. 7-Nomosaki.
}

Material Examined: Two large specimens (Pl. VI, figs. 12-13) imbedded in the coral Platygyra lamellina (EHRENBERG) from Kusimoto, Wakayama-ken (purchased, 1966) and many shells from faviid corals collected in Tanabe Bay.

Size of Largest specimens. Carino-rostral diameter of shell $18 \mathrm{~mm}$; Longest diameter of orifice $3 \mathrm{~mm}$; width of shell $13 \mathrm{~mm}$; depth of basis $22 \mathrm{~mm}$.

Supplementary Description: Of the two large specimens figured here, one has a nearly flat shell exposed wholly on the surface of the host coral, while the other has a slightly conical shell partly exposed. Both are provided with about 31 prominent ribs radiating from the apex around the orifice and strongly plicated toward the circumference. These ribs are high, narrow and crenulated at tip.

The shell is white tinged with rosy hue. Externally there are no trace of radii, thus the four compartments are completely fused together.

In internal aspect, however, there are four distinct sutures on the finely striated broad sheath which occupies the upper two-thirds of the length of the wall. The rostrum is intermediate in width between the carina and lateralia, although its own width is variable in specimens. The lower edge of the sheath is quite free from the inner wall. The sutural edges of the wall-plates are simply dentated as in other Balanomorph barnacles. The inner surface of the wall below the sheath is deeply hollowed and more or less distinctly costate toward the marginal dentations. The hollow between the costae is of ten here and there permeated by several rows of pores. However, these pores, when present, are confined only to the basal margin, never extending upwards like such parietal tubes as seen in ordinary Balanus, the wall plate being essentially solid.

In the initial stage of shell development, the 4 shell-plates are completely separated and their wall is quite solid (though thin) without any distinct demarcation of the sheath and the inner wall (cf. UTINOMI, 1943). In more advanced stages of calcification, the sheath and the marginal wall are connected together by the inner costae. If the sheath is interpreted as the "inner lamina" not developing the lower wall 


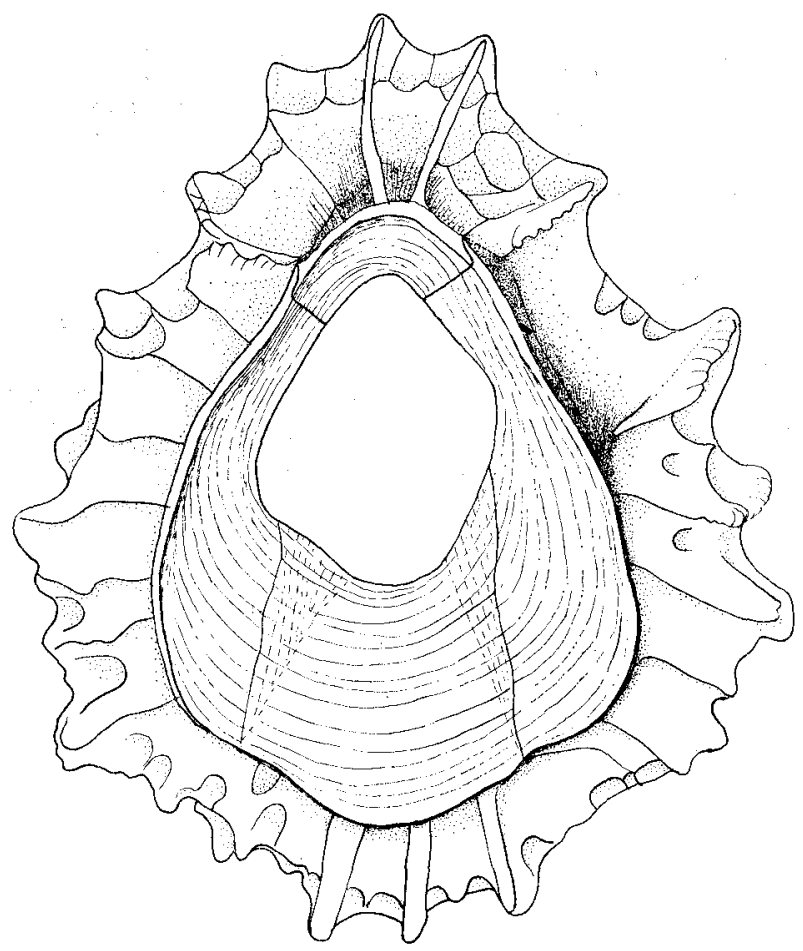

Text-fig. 17. Creusia indica (ANNAndale). Inner view of shell. $\times 9$
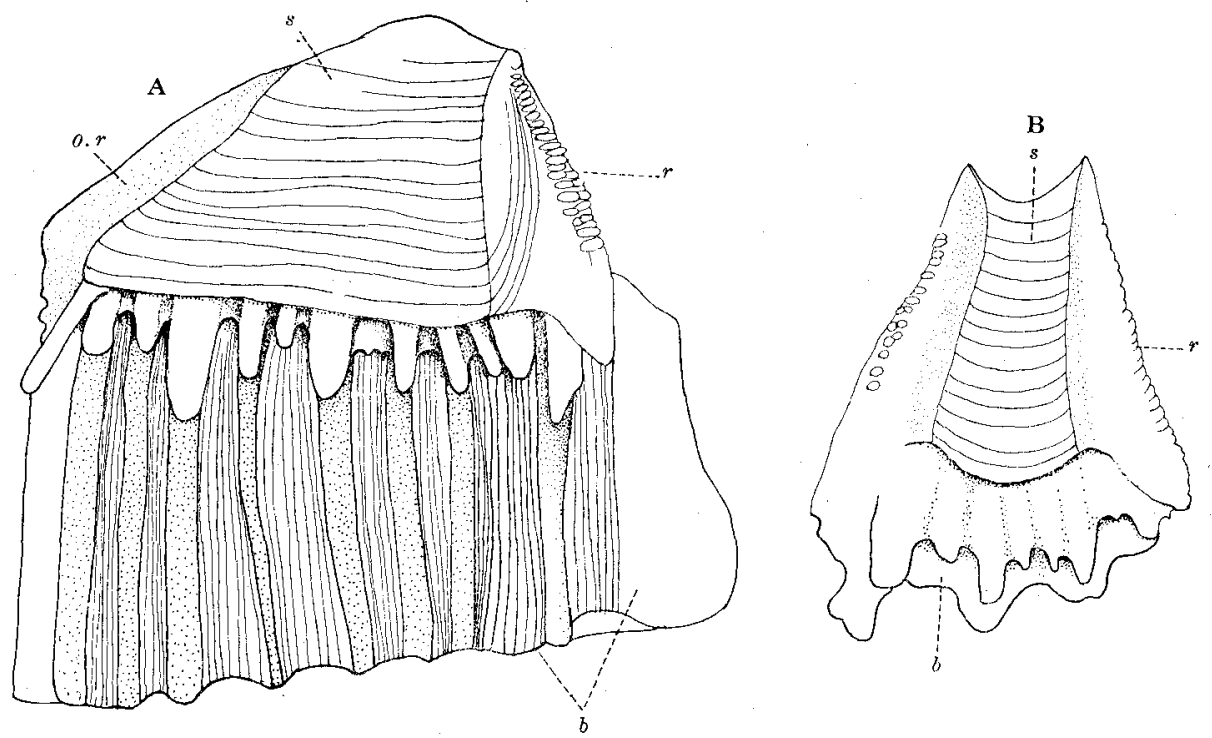

Text-fig. 18. Creusia indica (Annandate) from Platygyra lamellina.

A, lateral compartment and part of porous basal wall, inner view. B, rostrum and part of poreless basal wall, inner view. All $\times 9$

$b$-basis; $o . r$-outer rib on shell; $r$-radius; $s$-sheath. 
and the marginal wall as the true "outer lamina", these connecting ribs may correspond to the "primary longitudinal septa" of ordinary barnacles and hence the marginal basal pores may be interpreted as the secondary pores formed at the base of the "outer lamina".

The discussion presented here may be too much speaking, since apparently similar case is met with in the other Balanomorphs such as Balanus (Semibalanus), Tetraclita (Tesseropora), Chelonibia and Platylepas, all with membranous basis (also see Ross and Newman, 1967). In any way, such abnormally perforated structure may depend on a secondary phenomenon occurring in the process of calcification or marginal growth.

The wall of the basal cup imbedded deeply in the coral skeleton is either solid or porous. In the latter case, the inside of the basal wall is prominently ribbed. These ribs, which contain empty longitudinal tubes within, are finely striated on the surface, and the marginal projections or denticles of the shell-wall tightly interlock with the deep furrows between these ribs at the top of the basal cup.

Habitat and Distribution: Widely distributed in the Indo-west-Pacific area, harbouring commonly on astraeid or meandroid reef corals, such as Favia speciosa, Favites favosa, Platygyra lamellina, Lithophyllon lobata, Caulastrea tumida, Leptastrea purpurea, Echinophyllia aspera, Hydnophora exesa, Merulina ampliata, Acanthastrea echinata, Lobophyllia robusta, Symphyllia recta, Pectinia lactuca, etc.

\section{Megatrema oulastreae (UTINOMI)}

\section{(Japanese name: Toge-sangohuzitubo)}

(Text-figs. 19-20)

\footnotetext{
Pyrgoma anglicum: Hiro, 1935, p. 53 (Fig. 4 is real Pyrgoma (Megatrema) anglicum Sowerby, attached to Caryophyllia smithi from Plymouth, England); Hiro, 1937, p. 467-Tanabe Bay (on Psammocora).

Creusia spinulosa LeAGH forma quarta: Utinomi, 1949, p. 35, fig. 6-Tomioka (on Oulastrea crispata). (not Kolosváry)

Pyrgoma oulastreae Utinomi, 1962, p. 227, figs. 6-8-Nomosaki (on Oulastrea crispata).

Megatrema oulastreae: Uтіломг, 1966, p. 8 (listed only)-Tomioka and Nomosaki.
}

Material Examined: (1) Holotype and paratype specimens on Oulastrea crispata (Lamarck) from Nomosaki. Coll. Mr. K. Matsubayashi, 19-III-1961. (2) 6 specimens on Oulastrea crispata (LAmarck) from Bansyozaki, Seto, SW of Tanabe Bay. Coll. H. Utinomi, 1964. (3) 7 specimens on Psammocora profundacella Gardiner from Bansyozaki, Seto, SW of Tanabe Bay. Coll. H. Uтіnomi, 1934.

Holotype. Deposited in the museum of the Seto Marine Biological Laboratory, registering as SMBL-Type 187.

Size of Specimens from Seto:

(2) Specimens on Oulastrea crispata. 


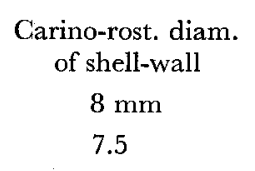

6

Height of
shell-wall
$4 \mathrm{~mm}$
4
2

2

$\begin{array}{lc}\begin{array}{c}\text { Longest diam. } \\ \text { of orifice }\end{array} & \begin{array}{c}\text { Depth of } \\ \text { basal cup }\end{array} \\ 2 \mathrm{~mm} & - \\ 2 & 4 \mathrm{~mm}\end{array}$

2

(3) Specimens on Psammocora profundacella.

Carino-rost. diam.
of shell-wall
$6 \mathrm{~mm}$
5
4
3

$\begin{gathered}\text { Height of } \\ \text { shell-wall }\end{gathered}$
$2 \mathrm{~mm}$
2
1.7
1.4

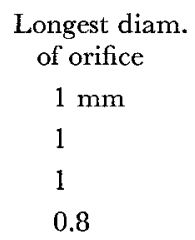

Supplementary Description: The shell-wall completely covered with the host coral skeleton is low conical or somewhat depressed and nearly round in outline. The outer surface, when cleaned, is radially ribbed and strongly dentated around the circumference.
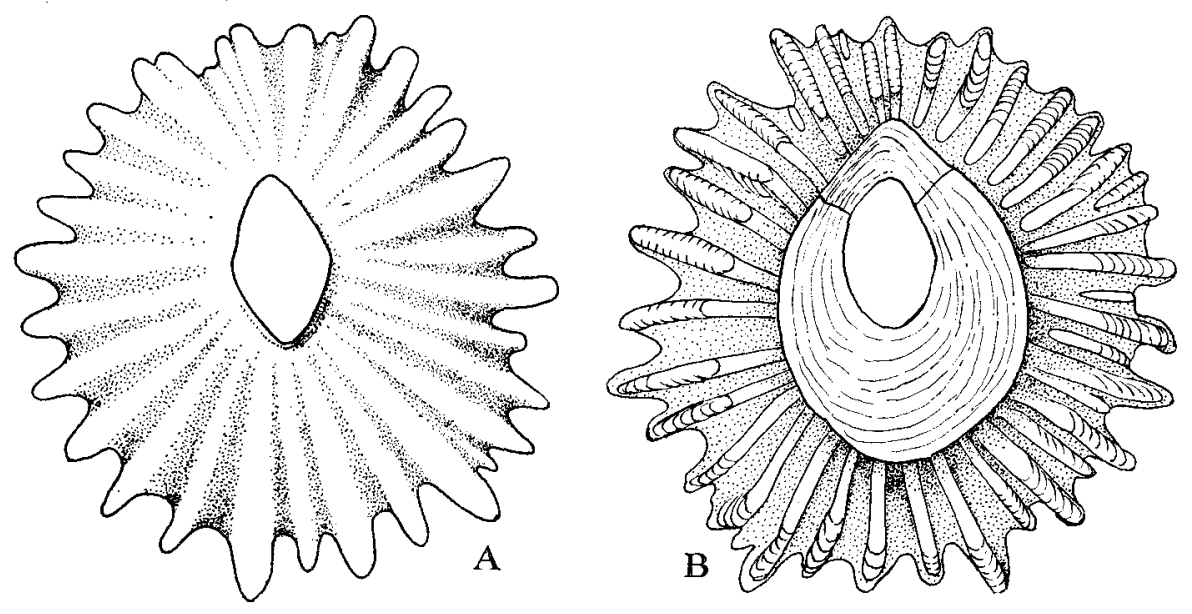

Text-fig. 19. Megatrema oulastreae from Psammocora profundacella.

$A$, shell, upper view. B, shell, inner view. All $\times 12$

The wall-plates are completely fused without any trace of sutures externally. The orifice is small, diamond-shaped to oval in outline. Internally, the sheath, occupying about one-half of the height of the wall is finely striated horizontally, and its lower edge is continuous and quite free from the inner face of the wall; there are only two distinct, straight sutures on the sheath separating the small carina from the fused compound compartments (lateralia + rostrum + lateralia). Below the sheath there are many prominent ribs radially arranged along the furrows lying inside of the outer ribs; the number of these ribs counted in one specimen figured here is approximately 31 primaries plus 8 secondaries. These inner ribs are very thick, solid and 
denticulate basally toward the marginal edge to connect with the apex of the basis.

The basis is shallow cup-shaped, and porous near the tip but gradually becomes thinner and solid toward the bottom center. The inside of the basis is barely furrowed.

The scutum is wider than high and strongly convex outside. Externally it is covered by an yellowish epidermis and hairy along the rather closely arranged growthlines; internally, the adductor ridge is prominent, barely reaching the convex basal margin; the articular ridge is long and gently curved.

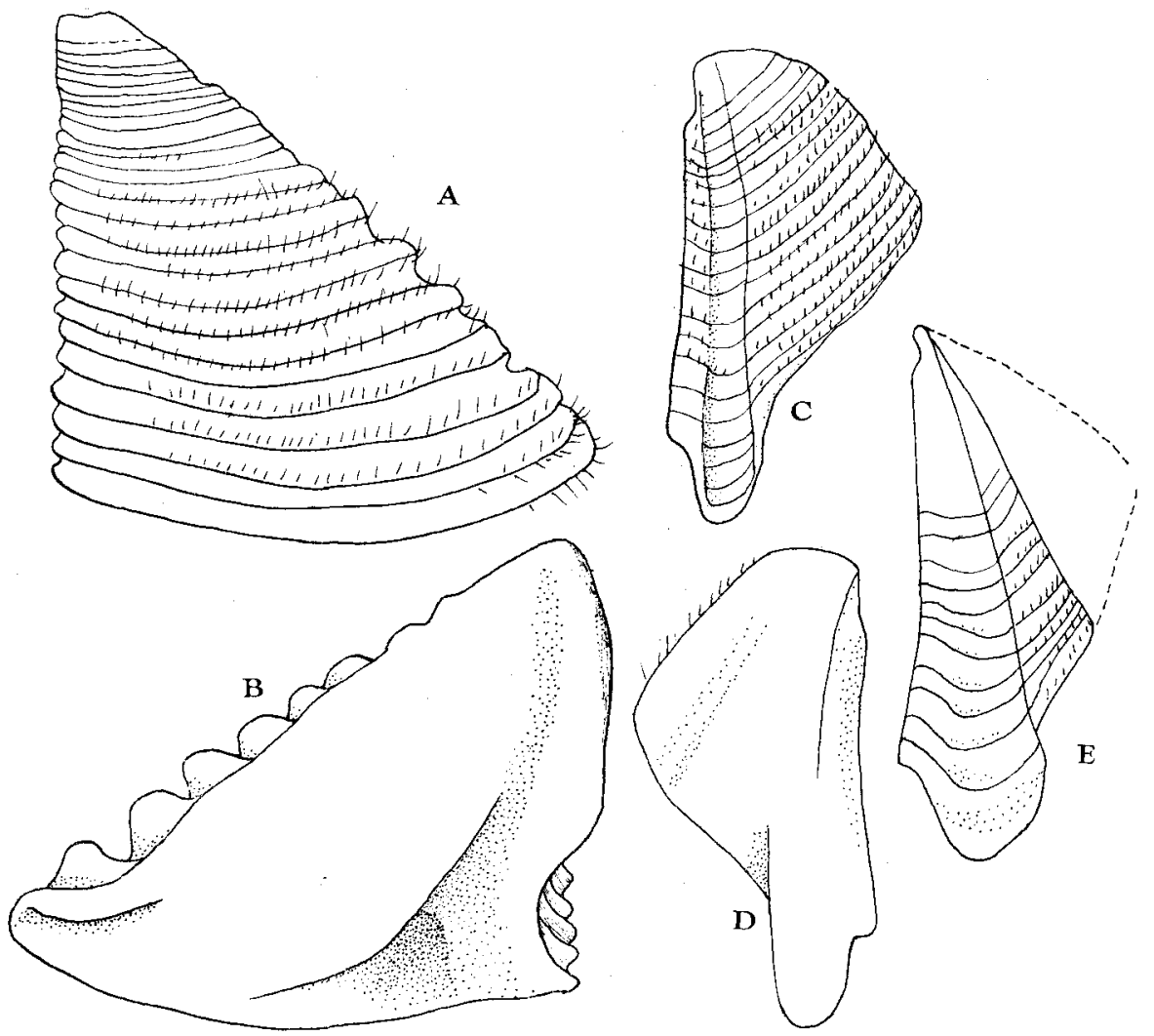

Text-fig. 20. Megatrema oulastreae (Uтімом) from Psammocora profundacella.

A, scutum, outer view. B, scutum, inner view. C, tergum, outer view. D, tergum, inner view. E, partly broken tergum, outer view. All $\times 33$

The tergum is rather narrow, with a short, roundly ended spur, slightly separated from the basi-scutal angle. Externally there is a broad but shallow spur-fasciole and the growth-lines are also fringed with hairs. The interior is quite smooth.

Remarks : Formerly I have referred the low conical specimens partly imbedded in Psammoqora profundacella Gardiner to Pyrgoma anglicum Sowerby (Hiro, 1935, p. 53). However, the real Pyrgoma anglicum is so far known only from the British waters 
(Darwin, 1854; Pilsbry, 1916; Rees, 1962, 1966) and the west African coast (Darwin, 1854; Broch, 1927b; Stubbings, 1964), harboring on ahermatypic corals such as Caryophyllia smithi Stokes \& BRoderip and Dendrophyllia cornigera LAMARGK. Later I (UTINomi, 1962, p. 227) have regarded apparently similar specimens occurred on a hermatypic coral Oulastrea crispata (LAMARCK) as a separate species of the genus Pyrgoma in the sense of Brooks and Ross (1960).

However, now I have arrived at a conclusion that the coral-inhabiting corals should be divided into several groups according to the grade of fusiion of compartments in the wall from phylogenetical viewpoint, following a suggestion of NEWMAN and Ross (Ross, 1964 in litt.). Although their paper was not yet published, I feel it most timely to present here an example in support of an idea of reviving the taxa rejected by DARWIN and successors on the occasion of redescribing the material here concerned.

The genus Megatrema was first erected by LEAGH (1825) for Pyrgoma anglica Sowerby (1823) and Megatrema stockesii Gray (1825). These two species have only two sutures on the sheath one on each side towards its carinal end, as do $M$. oulastreae. The three species assignable to Megatrema can be differentiated by the following key:

Shell steeply conical, ribbed only at base, with weakly plicated circumference; basis cup-shaped

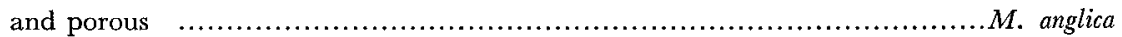

Shell low conical, strongly ribbed, with strongly dentated circumference; basis cup-shaped and

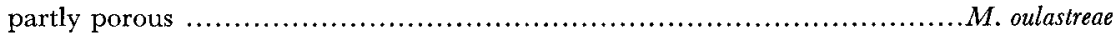

Shell flat, beadedly ribbed, with plain circumference; basis cylindrical and non-porous M. stockesi

Habitat and Distribution: Definitely known from southern Japan, harboring on the encrusting reef corals, Oulastrea crispata (LAMARGK) and Psammocora profundacella Gardiner.

BRoch (1931) referred one specimen on a Fungiid coral from off Toeal, Kei Islands to Pyrgoma anglicum with some hesitation, as the shell having distinct radiating ribs all over and at the same time he regarded another dried specimen on a coral taken from deep water $(200 \mathrm{~m})$ of Sagami Sea, Japan as "Pyrgoma aff. anglicum SowERBy." Inferring from BROAH's note, the former from Kei Islands may be the same as or allied to $M$. oulastreae here described, and the latter from Sagami Sea may be the real $M$. anglica or identical with an unnamed variety of $P$. anglicum which SAKakurA (1934, p. 575, figs. 1-4) reported from the Pleistocene of Tiba Prefecture where is well known as abundant of fossil corals and located not far from Sagami Sea, as occurring on a simple coral Heterocyathus (Stephanoseris) carthausi Felix. Besides, the typical $P$. anglicum was recorded by Nilsson-Cantell (1938b) from Ganjan coast, Madras, Bay of Bengal, 44-45 m, as occurring on Caryophyllia sp.

From all earlier records of occurrence it is deduced that Megatrema anglica (= Pyrgoma anglicum) is probably an obligatory commensal on ahermatypic or deep-sea corals, such as Caryophyllia, Dendrophyllia, Leptopsammia, Paracyathus, Cladocora, etc., 
distributing widely in all seas, particularly common on the continental shelf of the eastern Atlantic Ocean. Another little known $M$. stockesi seems to be confined to the West Indies and Florida area, occurring on the hermatypic coral Agaricia agaricites (Pallas).

\section{Acknowledgments}

I am indebted to many persons mentioned repeatedly in the text for supplying pertinent material as gifts or on loan during the course of this study, especially to Dr. Torben Wolff (Copenhagen Museum), Miss Elizabeth G. Pope (Australian. Museum, Sydney), Miss Eyvor E. SAndison (Westfield College, London) and Mr. Arun Wagh (Institute of Science, Bombay) for the type specimens or many local materials abroad. My thanks are also due to Dr. Shin-ichiro Fuse and Mr. Hidetomo TANASE of our Laboratory for the help of photographing the specimens.

\section{REFERENCES}

Annandale, N. 1924. Cirripedes associated with Indian corals of the families Astraeidae and Fungiidae. Mem. Ind. Mus., vol. 8, pp. 61-68, pl. 1.

BRoch, Hj. 1922. Papers from Dr. Th. Mortensen's Pacific Expedition 1914-16. X. Studies on Pacific cirripeds. Vidensk. Meddel. Dansk naturh. Foren., vol. 73, pp. 215-358.

1927a. Cambridge Expedition to the Suez Canal, 1924. Report on the Crustacea Cirripedia. Trans. Zool. Soc., Lond., vol. 22, pp. 133-138.

- 1927b. Studies on Moroccan cirripeds (Atlantic coast). Bull. Soc. Sci. Nat. Maroc, vol. 7 (1-3), pp. 11-38, pls. 1-4.

1931. Papers from Dr. Th. Mortensen's Pacific Expedition 1914-16. LVI. Indomalayan

Cirripedia. Vidensk. Meddel. Dansk naturh. Foren., vol. 91, pp. 1-146.

BRooks, H.K. and A. Ross 1960. Pyrgoma prefloridanum, a new species of cirriped from the Caloosahathee Marl (Pleistocene) of Florida. Crustaceana, vol. 1 (4), pp. 353-365, pls. 5-6.

Cornwali, Ira E. 1956. Identifying fossil and recent barnacles by the figures in the shell. Jour. Paleon., vol. 30 (3), pp. 646-651.

1958. Identifying recent and fossil barnacles. Can. J. Zool., vol. 36, pp. 79-89.

1959. More shell figures and notes on barnacles. Ibid., vol. 37, pp. 403-405, pls. 1-3.

Daniel, A. 1956. The Cirripedia of the Madras coast. Bull. Madras Govt. Mus., n. s. Nat. Hist. Sect., vol. 6 (2), pp. 1-40, 10 pls.

Darwin, Ch. 1854. A monograph on the sub-class Cirripedia. The Balanidae, the Verrucidae, etc. Ray Society, London. viii +684 pp., 30 pls.

Davadie-Sundeau, Claude 1952. Contribution a l'étude des Balanidés tertiaries de l'Algerie. Bull. Serv. Carte Géol. Algérie, Ser. 1, Paléontol., no. 14, pp. 36-43.

Davadie, Claude 1963. Systématique et structure des Balanes fossilles d'Europe et d'Afrique. Éd. Centr. Natl. Rech. Sci., Paris. 146 pp., 55 pls.

Gruvel, A. 1903. Revision des cirrhipèdes appartenant a la collection du Muséum d'Histoire Naturelle. Operculés. I.-Partie Systematique. Nouv. Arch. Mus. Hist. nat., Paris, Ser. 4, vol. 5, pp. 95-170, pls. 1-4.

1904. Revision des Cirrhipèdes appartenant a la collection du Muséum d'Histoire naturelle. Cirrhipèdes Thoraciques. II.-Partie Anatomique. Ibid., Ser. 4, vol. 6, pp. 51-224, pls. 1-8.

$1-472$. 
Harding, J. P. 1962. Darwin's type specimens of varieties of Balanus amphitrite. Bull. Brit. Mus. (Nat. Hist.), Zool., vol. 9 (7), pp. 273-296, pls. 1-10.

Henry, Dora P. 1958. Intertidal barnacles of Bermuda. Jour. Mar. Res., vol. 17, pp. 215-234. 1959. The distribution of the amphitrite series of Balanus in North American waters. In D. L. RAY (ed.): Marine boring and fouling organisms (Friday Harbor Symposia), Univ. Wash. Press, Seattle, pp. 190-203, pls. 1-4.

Hiro, F. 1935. A study of cirripeds associated with corals occurring in Tanabe Bay. Rec. Oceanogr. Wks. Japan, vol. 7 (1), pp. 45-72.

1937. Studies on Cirripedian fauna of Japan. II. Cirripeds found in the vicinity of the Seto

Marine Biological Laboratory. Mem. Coll. Sci., Kyoto Imp. Univ., Ser. B, vol. 12 (3), pp. 385-478. -1938a. On the Japanese forms of Balanus amphitrite Darwin. Zool. Mag. (Japan), vol. 50 (6), 299-313. [In Japanese, with English resumé.]

1938b. Studies on the animals inhabiting reef corals. II. Cirripeds of the genera Creusia and Pyrgoma. Palao Trop. Biol. Sta. Studies, vol. 1 (3), pp. 391-416, pl. 1.

1939. Studies on the Cirripedian fauna of Japan. IV. Cirripeds of Formosa (Taiwan), with some geographical and ecological remarks on the littoral forms. Mem. Coll. Sci,, Kyoto Imp. Univ., Ser. B, vol. 15 (2), pp. 245-284.

Hozk, P. P. G. 1913. The Cirripedia of the Siboga Expedition. B. Cirripedia Sessilia. Siboga-Expeditie, mon. 31B, pp. 128-275, pls. 11-27.

Kawahara, T. 1961. Regional differences in the composition of fouling communities in Ago Bay. Rep. Fac. Fish. Pref. Univ. Mie, vol. 4 (1), pp. 65-80.

KaWAhara, T. and H. Irjima 1960. On the constitution of marine fouling communities at various depths in Ago Bay. Ibid., vol. 3 (3), pp. 582-594.

Kolosváry, G. 1939. Beträge zur Variabilität der Cirripedien-Unterart Balanus amphitrite communis Darwin. Zool. Anz., vol. 126 (5/6), pp. 129-137.

1947. New data of cirripeds associated with corals. Ann. Mag. Nat. Hist., Ser. 11, vol. 14, pp. 358-368.

1948. New balanids from the middle Miocene of Várpalota in Hungary. Földtani Közlöng, vol. 78 (1-12), pp. 102-112. [In Hungarian, with English summary.] $149-154$.

1962a. Further fossile balanids from the USSR. Acta Biol., Szeged, n. s., vol. 7 (3/4), pp.

- 1962b. Balanids from the Bulgarian Tertiary age. Ann. Univ. Sofia, vol. 55 (2, Geol.), pp. 85-89, pls. 1-3.

1962c. Káspi-és Aral-Tó Környéki Neogén balanidák. Magyar Tudom. Akad. Biol. Tudom.

Osztál. Közleményei, no. 3-4, pp. 203-216. [In Hungarian.] 193-197.

1962d. New micro-balanids from Tongatabu. Acta Biol., Szeged., n. s., vol. 8 (1-4), pp.

KrüGer, P. 1911. Beiträge zur Cirripedienfauna Ostasiens. K. Bayer. Akad. Wiss. II. Suppl.-Bd. 6 Abhandl., 72 pp., 4 pls. München.

Mawatari, Sh., Hirosaki, Y. and S. Kobayashi 1954. Settlement and growth of acorn barnacle, Balanus amphitrite communis Darwin. I-II. Misc. Rep. Res. Inst. Nat. Res., no. 33, pp. 46-55; no. 34, pp. 48-57, pl. 1 .

Newman, W.A., Zullo, V.A. and St. Wainwright 1967. A critique on recent concepts of growth in Balanomorpha (Cirripedia, Thoracica). Crustaceana, vol. 12 (2), pp. 167-178, pls. 46.

Nilsson-Cantell, C.-A. 1921. Cirripedien-Studien. Zur Kenntnis der Biologie, Anatomie und Systematik dieser Gruppe. Zool. Bidrag Uppsala, vol. 7, pp. 75-390, p]s. 1-3.

1925. Neue und wenig bekannte Cirripedien aus den Museen zu Stockholm und zu Upsala. Ark. Zool., vol. 18A (3), pp. 1-46, pl. 1.

- 1931. Revision der Sammlung recenter Cirripedien des Naturhistorischen Museums in

Basel. Verhandl. Naturf. Ges. Basel, vol. 42, pp. 103-137, pl. 2.

1932. Cirripedien aus Japan gesammelt von Dr. Smith, Dr. Haberer und Dr. Hilgendorf,

in dem Berliner Museum aufbewahrt. Ark. Zool., vol. 24A (4), pp. 1-30, pl. 1. 
1934a. Indo-Malayan cirripeds in the Raffles Museum, Singapore. Bull. Raffles Mus. Singapore, no. 9 , pp. $42-73$, pl. 5 .

1934b. Cirripeds from the Malay Archipelago in the Zoological Museum of Amsterdam. Zool. Meded. Leiden, vol. 17 (1-2), pp. 31-63.

- 1938a. Recent cirripeds from the Congo. Rev. Zool. Bot. Afr., vol. 31 (1), pp. 175-

181.

1938b. Cirripeds from the Indian Ocean in the collection of the Indian Museum, Calcutta. Mem. Ind. Mus., vol. 13 (1), pp. 1-81, pls. 1-3.

Pilsbry, H.A. 1907. Hawaiian Cirripedia. Bull. Bur. Fish., vol. 26, pp. 179-190, pls. 4-5. 1916. The sessile barnacles (Cirripedia) contained in the collections of the U.S. National Museum; including a monograph of the American species. U.S. Nat. Mus. Bull. 93, pp. i-xi, 1366 , pls. $1-76$.

1928. Littoral barnacles of the Hawaiian Islands and Japan. Proc. Acad. Nat. Sci. Philadelphia, vol. 79 (1927), pp. 305-317, pls. 24-26.

1931. The cirriped genus Pyrgoma in American waters. Ibid., vol. 83, pp. 81-83.

Pope, E.C. 1945. A simplified key to the sessile barnacles found on the rocks, boats, wharf piles and other installations in Port Jackson and adjacent waters. Rec. Australian Mus., vol. 21 (6), pp. 351-372, pls. 28-30.

1966. Port Phillip Survey 1957-1963. Sessile barnacles Thoracica, Cirripedia. Mem. Nat. Mus. Victoria, Melbourne, no. 27, pp. 179-182.

ReEs, W.J. 1962. The distribution of the coral Caryophyllia smithii and the barnacle Pyrgoma anglicum in British waters. Bull. Brit. Mus. (Nat. Hist.), Zool., vol. 8 (9), pp. 403-418, pl. 12.

1966. Further notes on the distribution of Caryophyllia smithii Stokes \& Broderip and Pyrgoma anglicum Sowerby. Ann. Mag. Nat. Hist., Ser. 13, vol. 9 (100-102), pp. 289-292.

Rogers, F.L. 1949. Three new subspecies of Balanus amphitrite from California: Jour. Ent. and Zool., vol. 41 (2), pp. 23-32, pl. 1.

Ross, A. 1962. Results of the Puritan-American Museum of Natural History Expedition to western Mexico. 15. The littoral Balanomorph Cirripedia. Amer. Mus. Novitates, no. 2084, pp. 1-44.

1964. Personal communication. June 30.

Ross, A. and W.A. Newman 1967. Eocene Balanidae of Florida, including a new genus and species with a unique plan of "turtle-barnacle" organization. Amer. Mus. Novitates, no. 2288, pp. 1-21.

Sakakura, K. 1934. On the fossil Pyrgoma anglicum Sowerby found in the Pleistocene of the Tiba Prefecture. Jour. Geol. Soc. Japan, vol. 41 (493), pp. 575-581. [In Japanese and English.]

Sandison, E.E. 1962. The populations of Balanus amphitrite var. siutsburi on the Guinea coast. Proc. Zool. Soc. Lond., vol. 138 (4), pp. 517-542.

Southward, H.J. and D.J. CRisp 1963. Barnacles of European waters. Catalogue of main fouling organisms, vol. 1, pp. 1-46. O.E.C.D. Publ., Paris.

Stubbings, H.G. 1961a. Some Cirripedia from the Persian Gulf. Ann. Mag. Nat. Hist., Ser. 13, vol. 4, pp. 171-176.

- 1961b. Campagne de la Calypso dans le golfe de Guinée et aux îles Principe, São Tomé, Annobon (1956) (suite.) 11. Cirripedia. Res. Sci. Camp. "Calypso", fasc. 5, pp. 179-192.

$7-41$.

- 1961c. Cirripedia Thoracica from tropical West Africa. Atlantide-Rep., no. 6, pp.

1963a. Cirripedia from South Vietnam. Vidensk. Medd. fra Dansk naturh. Foren., vol. 125 , pp. $327-335$.

1963b. Cirripedia of the tropical South Atlantic coast of Africa. Exp. Ocean. Belge Eaux Cot. Afr. de l'Atlantique Sud (1948-1949), Res. Sci., vol. 3 (10), pp. 1-39.

1964a. Campagne de la "Calypso" Iles du Cap Vert. 4. Cirripedia. Res. Sci. Campagn.

"Calypso", fasc. 6, pp. 103-112.

1964b. Cirripedia from the Congo estuary and adjadent coasts in the Musée Royal de

l'Afrique Centrale, Tervuren, Belgium. Rev. Zool. Bot. Afr., vol. 69 (3/4), pp. 327-347.

- 1965. West African Cirripedia in the collections of the Institut Français d'Afrique

Noire, Dakar, Senegal. Bull. de l'IFAN., vol. 27 A (3), pp. 876-907. 
Tarasov, N.I. and G.B. Zevina 1957. Cirripedia Thoracica in the seas of USSR. Fauna SSSR, vol. 6, no. 1, pp. 1-268, 3 pls. [In Russian.]

Urinom, H. 1943. The larval stages of Creusia, the barnacle inhabiting reef corals. Annot. Zool. Japon., vol. 22 (1), pp. 15-22.

1949. Studies on the Cirripedian fauna of Japan. VI. Cirripeds from Kyusyu and Ryukyu

Islands. Publ. Seto Mar. Biol. Lab., vol. 1 (2), pp. 19-37.

1956. Coloured illustrations of seashore animals of Japan. Hoikusha, Osaka. pp. i-xvii, 1-168, pls. 1-64, I-XII. [In Japanese.]

1958. Studies on the Cirripedian fauna of Japan. VII. Cirripeds from Sagami Bay.

Publ. Seto Mar. Biol. Lab., vol. 6 (3), pp. 281-311.

1960. On the world-wide dispersal of a Hawaiian barnacle, Balanus amphitrite hawaiiensis

Broch. Pacific Sci., vol. 14 (1), pp. 43-50.

1962. Studies on the Cirripedian fauna of Japan. VIII. Thoracic cirripeds from western

Kyusyu. Publ. Seto Mar. Biol. Lab., vol. 10 (2), pp. 211-239.

1964. Coloured illustrations of seashore animals of Japan. Revised 8th printing (Cirripedia: pp. 49-53, pls. 25-26). Hoikusha, Osaka.

Utinomi, H. and T. Kikushi 1966. Cirriped Crustacea. Fauna and Flora of the Sea around the Amakusa Marine Biological Laboratory, Part VI, pp. 1-11. [In Japanese.]

Weisbord, N.E. 1965. Some late Cenozoic cirripesds from Venezuela and Florida. Bull. Amer. Paleont., vol. 50 (225), pp. 1-145, pls. 1-10.

Withers, T.H. 1926. Barnacles of the Creusia-Pyrgoma type from the Pleistocene of Barbados. Ann. Mag. Nat. Hist., Ser. 9, vol. 17, pp. 1-6, pl. 1.

1929. The phylogeny of the cirripedes Creusia and Pyrgoma. Ibid., Ser. 10, vol. 4, pp, 559-566, pls. 10-11.

Zevina, G.B. and N.I. Tarasov 1963. On the Cirripedian fauna (Cirripedia Thoracica) on the continental coast of the south-eastern Asia, pt. 1. Trudy Inst. Okéan., vol. 70, pp. 76-100. [In Russian, with English resumé.] 


\section{EXPLANATION OF PLATE VI}

Fig. 1. Balanus amphitrite amphitrite Darwin sensu Harding from Tanabe Bay, upper view. $\times 1.6$

Fig. 2. Balanus albicostatus albicostatus PILSBRy from Hatake-zima, Tanabe Bay, aggregated. $\times 1$

Fig. 3. Balanus albicostatus formosanus HrRo from Luchiang, Taiwan, aggregated. Syntypes. $\times 1$

Fig. 4. Balanus uliginosus UтіNom (nom. nov.) from Omori, Tokyo Bay, aggregated. $\times 0.7$

Fig. 5. Balanus uliginosus Uтломі (nom. nov.) from Tatigatani, Tanabe Bay, upper view. Lectotype. $\times 1.4$

Fig. 6. Balanus uliginosus Utinom (nom. nov.) from Tatigatani, Tanabe Bay, side view. Lectotype. $\times 1.4$

Fig. 7. Balanus reticulatus UTinomi (nom. nov.) from Tatigatani, Tanabe Bay, upper view. Lectotype. $\times 1.4$

Fig. 8. Balanus reticulatus Utrnomi (nom. nov.) from Tatigatani, Tanabe Bay, side view. Lectotype. $\times 1.4$

Fig. 9. Acasta spinifera Utinomi (spec. nov.) from off Mera, mouth of Tokyo Bay, side view. Holotype. $\times 2$

Fig. 10. Rostrum of Acasta spinifera Utrinom (spec. nov.). Paratype B, outer view. $\times 2.2$

Fig. 11. Carino-lateral compartment of Acasta spinifera Utinomi (spec. nov.), Paratype $B$, outer view. $\times 2.2$

Fig. 12. Creusia indica (ANNANDale) imbedded in the coral Platygyra lamellina (EhrenberG) from Kusimoto, side view. $\times 1$

Fig. 13. Creusia indica (AnNandale) imbedded in the coral Platygyra lamellina (EhrenterG) from Kusimoto, side view. $\times 1$

Fig. 14. Fused scutotergum of the same, inner view. $\times 1.3$

Fig. 15. Fused scutotergum of the same, outer view. $\quad \times 1.3$

Fig. 16. Shell-plates of the same, broken into 3 pieces, inner view. $\times 1.3$ 


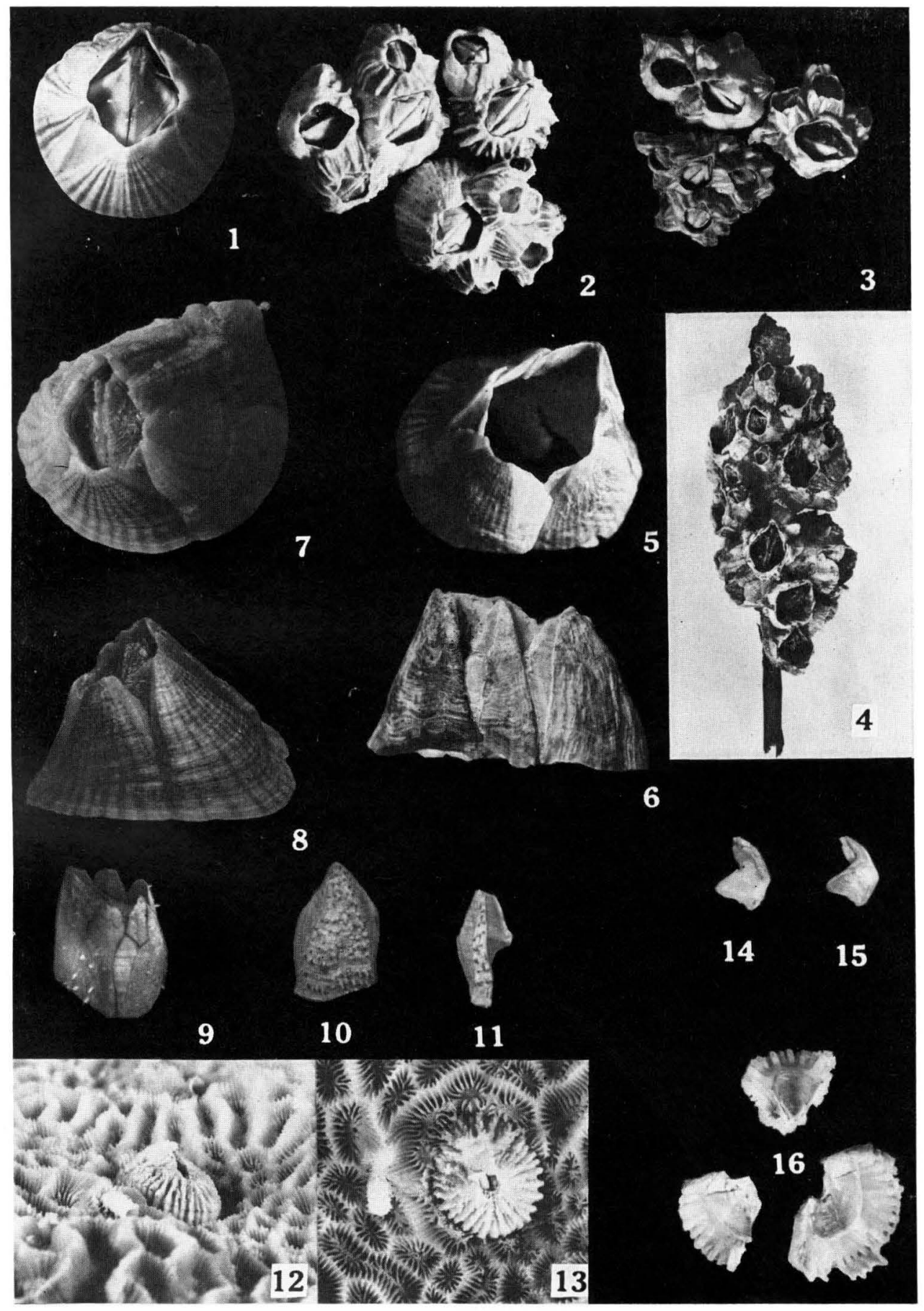

H. Utinomi: Comments on Some New and Already Known Cirripeds 